University of Nebraska - Lincoln

DigitalCommons@University of Nebraska - Lincoln

\title{
Lysine Optimization of a Commercial Fishmeal-Free Diet for Hybrid Striped Bass (Morone chrysops $\times$ M. saxatilis)
}

Steven D. Rawles

USDA-ARS, steven.rawles@ars.usda.gov

S. Adam Fuller

USDA-ARS

Benjamin H. Beck

USDA-ARS

T. Gibson Gaylord

U.S. Fish and Wildlife Service

Frederic T. Barrows

USDA-ARS, Rick.Barrows@ars.usda.gov

See next page for additional authors

Follow this and additional works at: https://digitalcommons.unl.edu/usdaarsfacpub

Rawles, Steven D.; Fuller, S. Adam; Beck, Benjamin H.; Gibson Gaylord, T.; Barrows, Frederic T.; and McEntire, Matthew E., "Lysine Optimization of a Commercial Fishmeal-Free Diet for Hybrid Striped Bass (Morone chrysops $\times$ M. saxatilis)" (2013). Publications from USDA-ARS / UNL Faculty. 1397.

https://digitalcommons.unl.edu/usdaarsfacpub/1397

This Article is brought to you for free and open access by the U.S. Department of Agriculture: Agricultural Research Service, Lincoln, Nebraska at DigitalCommons@University of Nebraska - Lincoln. It has been accepted for inclusion in Publications from USDA-ARS / UNL Faculty by an authorized administrator of DigitalCommons@University of Nebraska - Lincoln. 


\section{Authors}

Steven D. Rawles, S. Adam Fuller, Benjamin H. Beck, T. Gibson Gaylord, Frederic T. Barrows, and Matthew E. McEntire 


\title{
Lysine optimization of a commercial fishmeal-free diet for hybrid striped bass (Morone chrysops $\times$ M. saxatilis)
}

\author{
Steven D. Rawles ${ }^{\mathrm{a}, *}$, S. Adam Fuller ${ }^{\text {a }}$, Benjamin H. Beck ${ }^{\mathrm{a}}$, T. Gibson Gaylord ${ }^{\mathrm{b}}$, \\ Frederic T. Barrows ${ }^{c}$, Matthew E. McEntire ${ }^{a}$ \\ a United States Department of Agriculture (USDA), Agricultural Research Service (ARS), Harry K. Dupree Stuttgart National Aquaculture Research Center, P.O. Box 1050, \\ Stuttgart, AR, 72160-1050, USA \\ ${ }^{\mathrm{b}}$ U.S. Department of the Interior, Fish and Wildife Service, Bozeman Fish Technology Center, 4050 Bridger Canyon Road, Bozeman, MT 59715, USA \\ c USDA, ARS, Small Grains and Potato Germplasm Research Unit, Hagerman Fish Culture Experiment Station, 3059F National Fish Hatchery Road, Hagerman, ID 83332, USA
}

\section{A R T I C L E I N F O}

\section{Article history:}

Received 3 December 2012

Received in revised form 12 February 2013

Accepted 13 February 2013

Available online 5 March 2013

\section{Keywords:}

Hybrid striped bass

Ideal protein

Lysine optimization

Fishmeal-free diet

\begin{abstract}
A B S T R A C T
Substitution of fishmeal with alternate proteins in aquafeeds often results in dietary imbalances of first-limiting essential amino acids (EAA) and poorer fish performance. This growth trial was undertaken to test the hypothesis that ideal protein theory accurately predicts first-limiting amino acids and optimum lysine level for a fishmeal-free, commercial-grade diet formulated for hybrid striped bass (HSB). The ideal model for formulation was the amino acid pattern of hybrid striped bass muscle. A negative control diet based on soybean (45\%), corn gluten (10\%), and poultry by-product (13\%) meals was formulated on an ideal basis to contain $18 \%$ lipid, 40\% crude protein (CP), 36\% digestible protein (DP) and 1.8\% Lys from intact sources. Met and Thr were then added at levels equivalent to $40 \%$ protein from HSB muscle to form a basal diet that was fortified with seven levels of Lys ( 2.2 to $6.4 \mathrm{~g} / \mathrm{g}$ diet) that bracketed the predicted ideal Lys requirement (3.5 g/g diet) for this formulation. Diets were extruded to achieve similar characteristics as a commercial-grade feed and fed to juvenile fish (118 g BW) for $84 \mathrm{~d}$. Response data were subjected to polynomial and exponential regression and the best model per response selected based on the lowest error (MSE) and $p$-values and the highest adjusted $\mathrm{R}^{2}$. Selected models were used to derive dietary Lys levels required to reach 95\% (R95) or 99\% (R99) of the minimum or maximum response. Final fish weights (328-369 g) increased linearly with increasing dietary Lys. Weight gain, average daily feed intake (1.42-1.7\%), and feed efficiencies at 4-, 8-, and 12-week intervals were modeled by cubic functions that yielded consistent R95 and R99 levels of about 2.4 and $4.3 \mathrm{~g}$ Lys/g diet, respectively. These values evenly bracketed the predicted ideal Lys requirement. Slightly higher Lys requirement was found for optimum FE at 4 weeks and smaller fish, as opposed to 8 or 12 weeks and larger fish. Whole body composition was unresponsive to diet Lys level; however, higher dietary Lys was required to minimize liver size (4.8 to $5.2 \mathrm{~g}$ Lys/g diet) than to minimize body fat ( 2.5 to $3.1 \mathrm{~g} \mathrm{Lys} / \mathrm{g}$ diet) or maximize muscle ratio ( 1.8 to $3.9 \mathrm{~g}$ Lys $/ \mathrm{g}$ diet). Whole body protein, lipid, energy, and EAA retentions were also consistent with cubic functions that generally confirmed the predicted ideal Lys requirement with notable exceptions. Retention of Lys decreased exponentially with increasing dietary Lys, whereas, Met retention decreased in a linear fashion, corroborating that Met was first-limiting in this diet formula, as predicted. Retention of Thr and branched-chain amino acids were optimized at higher Lys levels (3.9-4.5 g/g diet) than those required to maximize growth parameters. Protein accretion $(\mathrm{g} / \mathrm{fish} / \mathrm{d})$ responded quadratically to Lys intake predicting maximum deposition at 0.10 to $0.16 \mathrm{~g}$ Lys/fish/d. Histological assessment of intestines in fish fed these high-soybean meal test diets did not reveal any lesions associated with enteritis for any diet and overall normal intestinal morphology was observed in all fish sampled.
\end{abstract}

Published by Elsevier B.V.

\section{Introduction}

With the current emphasis on developing commercial aquaculture diets that minimize or eliminate inclusion of fishmeal, the use of alternate proteins in least-cost formulas often results in dietary imbalances of some essential amino acids (EAA) and poorer fish performance.

\footnotetext{
* Corresponding author. Tel.: +1 870673 4483; fax: +1 8706737710 .

E-mail address: steven.rawles@ars.usda.gov (S.D. Rawles).
}

Lysine, methionine, and threonine are typically identified as first limiting in fishmeal replacement diets and the order of limitation among these three will depend on the mix and composition of proteins in the formula, the requirement model used to optimize the formula, and the ingredient composition data employed to meet nutrient requirements of the animal. Diets formulated to meet essential nutrient needs based on tabulated ingredient composition typically perform poorer than those that also take into account the availability of nutrients to the fish of interest from the specific ingredients used in a particular 
formula. Secondly, diets formulated to meet amino acid requirements derived from dose-response experiments with purified or semipurified diets (Griffin et al., 1992; Keembiyehetty and Gatlin, 1992) often fall short of the performance of diets fortified with amino acids at levels and ratios suggested by alternative models of requirement. (Brown, 1995; Gaylord and Rawles, 2005; Small and Soares, 1998; Twibell et al., 2003). The lysine requirements of HSB bass, for example, have been reported to be $1.4 \%$ of the diet or $4 \%$ of the dietary protein by two independent laboratories using purified or semi-purified diets (Griffin et al., 1992; Keembiyehetty and Gatlin, 1992). However, subsequent research has demonstrated that this level of lysine was notably inadequate in supporting optimal growth and efficiency when diets were manufactured from ingredients common in commercial feeds (Gaylord and Rawles, 2005; Rawles et al., 2009; Small and Soares, 1998). Therefore dietary concentrations of lysine, when commercial style formulations and ingredients are used, are likely higher for HSB than the previously determined requirement estimates.

There has been a significant amount of research directed at optimizing first-limiting amino acids in fishmeal replacement diets, particularly lysine in plant-protein based formulas. Many of these studies employed dose-response diets that were based on both the composition and availability of essential nutrients determined in the fish of interest as well as in the specific batches of ingredients used for those diets, rather than a priori values from published composition tables. Therefore, species differences and batch-to-batch ingredient variability were removed as confounding factors, and very specific requirement estimates could be derived. One potential limitation of such studies, however, is that commercial feed mills use ingredient matrices developed over time for their formulation software and not necessarily updated with composition data from each batch of ingredient that enters the mill. Secondly, requirement estimates for first limiting amino acids may be missing for a particular species of interest, leaving uncertainty in the optimum level to set for formulation.

Ideal protein is one model of amino acid requirement that demands less data in terms of dose-response requirement estimates in the fish of interest. Rather diets are formulated to match the levels and ratios of essential amino acids in the profile of an appropriate tissue from the fish of interest, e.g., whole body or muscle, or in the primary protein being replaced, e.g., fishmeal, that putatively represents the perfect ratio among essential amino acids required for maintenance and production, i.e., the ideal protein (Boisen et al., 2000; Fuller et al., 1979, 1989). If the ideal protein profile is assumed constant then the requirements for all essential amino acids can be calculated when the requirement for one is determined. Since lysine is typically first limiting in diets and is not used to synthesize nitrogen containing compounds, the ideal profile is usually expressed relative to the requirement for available Lys. However, the crux of formulating high performing diets using an ideal model is the accuracy of both the nutrient composition and digestibility/availability coefficients of the ingredients chosen for inclusion in a particular diet as well as the lysine concentration deemed to meet the requirement. Whether the lysine requirement is as high as predicted using an Ideal EAA profile of HSB muscle and the established protein requirement based on fish meal diets, as previously suggested (Gaylord and Rawles, 2005; Rawles et al., 2009), has yet to be determined. Fortunately, Boisen et al. (2000) notes that "the accuracy of the ideal pattern does not rely on a correct estimate of the available amount of one particular amino acid." The question then arises, how robust is the muscle ideal protein model for diet formulation purposes when Lys is not first limiting, which can occur depending on the chosen mix of protein sources, and when composition and availability data are not determined in situ? Hence, the goal of this study was to test the hypothesis that ideal protein theory sufficiently predicts first-limiting amino acids and optimum Lys supplementation needed to maximize performance of a fishmeal-free diet for hybrid striped bass when combined with nutrient digestibility/ availability data obtained in feedstuffs of interest.

\section{Materials and methods}

\subsection{Diets and experimental design}

A practical diet for hybrid striped bass was formulated without fishmeal and supplemented with Met and Thr and varying levels of Lys to form a series of nine dose-response diets that were fed to triplicate tanks of juvenile sunshine bass for 12 weeks (Table 1 ). An unsupplemented (negative basal) diet (D1) based on soybean meal (45\%), corn gluten meal (10\%), and poultry by-product meal (13\%) was formulated on an ideal basis to contain $40 \%$ crude protein (CP), $36 \%$ digestible protein (DP), and 18\% lipid from a combination of menhaden fish oil (10\%), poultry fat (5.7\%) and intact sources. The ideal model for formulation was the amino acid pattern of hybrid striped bass muscle (Gaylord and Rawles, 2005) at 40\% DP. Coefficients of gross nutrient digestibility and amino acid availability determined in the protein sources in prior trials (Barrows et al., 2011) were used to formulate the negative basal diet. Based on those values, available Met $(0.57 \%)$, Lys (1.84\%), and Thr (1.44\%) in the D1 diet were predicted to be first, second, and third limiting, respectively, when compared to the ideal model (Table 2). However, based on the formulated total levels of sulfur amino acids (1.12\%), Lys (1.99\%), and Thr (1.55\%), predicted levels were replete with respect to their requirement estimates (Griffin et al., 1992, 1994; Keembiyehetty and Gatlin, 1992, 1993, 1997). Therefore, to test our hypothesis, a supplemented basal diet (D2) was formulated by adding Met (first-limiting) and Thr (third-limiting) at 7.5 and $8.8 \mathrm{~g} / \mathrm{kg}$, respectively, to the D1 formula to match levels in the ideal model (Table 2). The basal diet formula (D2) was then fortified with seven additional levels of lysine $\mathrm{HCl}$ (diets D3-D9) at the expense of wheat starch in increments of $0.325 \mathrm{~g}$ Lys $/ 100 \mathrm{~g}$ of diet. Hence, the supplemented diets (D2-D9) were targeted to contain 1.84, 2.17, 2.49, $2.82,3.14,3.47,5.09$, and $6.72 \mathrm{~g}$ available Lys/100 g diet, respectively. These concentrations amounted to 1.3 to 4.8 times the Lys requirement of HSB (NRC, 2011) and bracketed the predicted ideal requirement (3.47 Lys $\mathrm{g} / 100 \mathrm{~g}$ diet) for this formulation by nearly 2 fold on each side of the predicted requirement as previously suggested (Berge et al., 1998; Espe et al., 2007). Analyzed concentrations of Lys in the test diets (Table 2) were within 5\% of formulated levels except for diets D4 and D5 which were $12 \%$ and 16\% higher, respectively, than their targeted concentrations. Therefore, all statistical analyses and interpretation were based on the measured concentrations of Lys in the test diets.

Diets were manufactured with commercial methods starting with ingredient grinding, as needed, to a particle size of $<200 \mu \mathrm{m}$ using an air-swept pulverizer (Model 18H; Jacobsen, Minneapolis, MN). Ingredients minus fish oil were combined in a paddle mixer (Marion Mixers, Inc., Marion, IA) and extruded using a twin-screw cooking extruder (DNDL-44, Buhler AG, Uzwil, Switzerland) at the Bozeman Fish Technology Center, Bozeman, Montana. Diet mash was exposed to an average of $114{ }^{\circ} \mathrm{C}$ for 18 -s in five barrel sections and the last section was water cooled to an average temperature of $83^{\circ} \mathrm{C}$. Pressure at the die head varied from 300 to 580 psi depending on the diet formulation. The $5.0-\mathrm{mm}$ floating pellets were manufactured through a $3-\mathrm{mm}$ die and were then dried in a pulse bed drier (Buhler AG, Uzwil, Switzerland) for $20 \mathrm{~min}$ at $102{ }^{\circ} \mathrm{C}$ and cooled at ambient air temperatures for final moisture levels of $<10 \%$. Fish oil was applied using a Phlauer vacuum infusion coater (A \& J Mixing, Ontario, Canada) after the pellets were cooled. Diets were bagged and shipped to the USDA/ ARS - Harry K. Dupree Stuttgart National Aquaculture Research Center (HKDSNARC; Stuttgart, AR) where they were stored in a temperature controlled room until use.

\subsection{Fish, culture system, and feeding}

The feeding trial was conducted in tanks at HKDSNARC over an 84 day period from December 10, 2010 to March 7, 2011. Juvenile hybrid striped bass, Morone chrysops $\times$ M. saxatilis, that were 
Table 1

Composition ( $\mathrm{g} / \mathrm{kg}$ dry weight) of fishmeal-free diets fed to hybrid striped bass (118.4 $\pm 0.9 \mathrm{~g}$; average initial weight $\pm \mathrm{SE}$ ) for 12 weeks.

\begin{tabular}{|c|c|c|c|c|c|c|c|c|c|}
\hline \multirow[t]{2}{*}{ Ingredient } & \multicolumn{9}{|c|}{ Diet designation } \\
\hline & D1 & D2 & D3 & D4 & D5 & D6 & D7 & D8 & D9 \\
\hline Soybean meal ${ }^{1}$ & 450.0 & 450.0 & 450.0 & 450.0 & 450.0 & 450.0 & 450.0 & 450.0 & 450.0 \\
\hline Poultry by-product meal - pet-food grade ${ }^{2}$ & 131.5 & 131.5 & 131.5 & 131.5 & 131.5 & 131.5 & 131.5 & 131.5 & 131.5 \\
\hline Corn gluten meal ${ }^{3}$ & 100.0 & 100.0 & 100.0 & 100.0 & 100.0 & 100.0 & 100.0 & 100.0 & 100.0 \\
\hline Wheat starch ${ }^{4}$ & 86.8 & 65.5 & 61.3 & 57.2 & 53.0 & 48.8 & 44.6 & 23.8 & 2.9 \\
\hline Menhaden fish oil ${ }^{5}$ & 100.0 & 100.0 & 100.0 & 100.0 & 100.0 & 100.0 & 100.0 & 100.0 & 100.0 \\
\hline Poultry fat ${ }^{3}$ & 56.5 & 56.5 & 56.5 & 56.5 & 56.5 & 56.5 & 56.5 & 56.5 & 56.5 \\
\hline Vitamin premix ${ }^{6}$ & 5.0 & 5.0 & 5.0 & 5.0 & 5.0 & 5.0 & 5.0 & 5.0 & 5.0 \\
\hline Stay-C 35 & 0.3 & 0.3 & 0.3 & 0.3 & 0.3 & 0.3 & 0.3 & 0.3 & 0.3 \\
\hline Trace mineral mix ${ }^{7}$ & 1.0 & 1.0 & 1.0 & 1.0 & 1.0 & 1.0 & 1.0 & 1.0 & 1.0 \\
\hline Choline chloride $50 \%$ & 6.0 & 6.0 & 6.0 & 6.0 & 6.0 & 6.0 & 6.0 & 6.0 & 6.0 \\
\hline Dicalcium phosphate & 44.0 & 44.0 & 44.0 & 44.0 & 44.0 & 44.0 & 44.0 & 44.0 & 44.0 \\
\hline $\mathrm{KCl}$ & 5.6 & 5.6 & 5.6 & 5.6 & 5.6 & 5.6 & 5.6 & 5.6 & 5.6 \\
\hline $\mathrm{NaCl}$ & 2.8 & 2.8 & 2.8 & 2.8 & 2.8 & 2.8 & 2.8 & 2.8 & 2.8 \\
\hline $\mathrm{MgO}$ & 0.5 & 0.5 & 0.5 & 0.5 & 0.5 & 0.5 & 0.5 & 0.5 & 0.5 \\
\hline Grobiotic A & 10.0 & 10.0 & 10.0 & 10.0 & 10.0 & 10.0 & 10.0 & 10.0 & 10.0 \\
\hline Taurine & 0.0 & 5.0 & 5.0 & 5.0 & 5.0 & 5.0 & 5.0 & 5.0 & 5.0 \\
\hline DL-methionine & 0.0 & 7.5 & 7.5 & 7.5 & 7.5 & 7.5 & 7.5 & 7.5 & 7.5 \\
\hline Threonine & 0.0 & 8.8 & 8.8 & 8.8 & 8.8 & 8.8 & 8.8 & 8.8 & 8.8 \\
\hline Lysine $\mathrm{HCl}$ & 0.0 & 0.0 & 4.2 & 8.3 & 12.5 & 16.7 & 20.9 & 41.7 & 62.6 \\
\hline \multicolumn{10}{|l|}{ Analyzed composition (as-is) } \\
\hline Crude protein $(\mathrm{N} \times 6.25), \mathrm{g} / \mathrm{kg}$ & 398.8 & 415.6 & 403.5 & 396.9 & 438.2 & 434.6 & 437.9 & 455.5 & 473.0 \\
\hline Crude fat, $\mathrm{g} / \mathrm{kg}$ & 162.8 & 162.9 & 159.0 & 174.6 & 168.3 & 160.0 & 162.9 & 175.7 & 161.5 \\
\hline Gross energy, $\mathrm{MJ} / \mathrm{kg}$ & 20.2 & 20.0 & 19.9 & 20.4 & 20.5 & 20.2 & 20.5 & 20.4 & 20.4 \\
\hline Moisture, $\mathrm{g} / \mathrm{kg}$ & 35.6 & 45.8 & 38.5 & 36.7 & 40.5 & 35.6 & 39.1 & 47.2 & 35.6 \\
\hline Taurine, $\mathrm{g} / \mathrm{kg}$ & 0.0 & 5.3 & 5.3 & 5.0 & 4.9 & 4.8 & 5.1 & 5.2 & 4.6 \\
\hline \multicolumn{10}{|l|}{${ }^{1}$ ADM Inc., Decatur, IL; 480 g/kg protein. } \\
\hline \multicolumn{10}{|l|}{2 Tyson Foods, Inc., Sedalia, MO. } \\
\hline \multicolumn{10}{|c|}{${ }^{3}$ Nelson Silver Cup, Murray, UT. } \\
\hline \multicolumn{10}{|c|}{4 Manildra Milling, Shawnee Mission, KS; $4 \mathrm{~g} / \mathrm{kg}$ protein. } \\
\hline \multicolumn{10}{|c|}{5 Omega Protein, Inc., Reedville, VA. } \\
\hline \multicolumn{10}{|c|}{${ }^{6}$ Contributed, per kg of diet: vitamin A, $9650 \mathrm{IU}$; vitamin D, $6600 \mathrm{IU}$; vitamin E, $132 \mathrm{IU}$; vitamin K3, $1.1 \mathrm{mg}$; thiamin mononitrate, $9.1 \mathrm{mg}$; riboflavin 9.6 mg;; pyridoxine hydrochloride } \\
\hline
\end{tabular}

spawned and reared in-house were individually marked with passive integrated transponder (PIT) tags (Biomark, Inc., Boise, ID) in the dorsal musculature and acclimated to the culture system for four weeks prior to initiation of the feeding experiment. During the acclimation period, fish were fed a standard commercial $40 \%$ protein/12\% lipid hybrid striped bass feed (Cargill Nutrition, Franklinton, LA) at $1.5 \%$ of body weight/d to maintain good condition with minimal growth. Prior to the start of the experiment, all fish were pooled, then individually weighed (118.4 $\pm 0.9 \mathrm{~g}$; average initial weight \pm SE) and randomly stocked ( 35 fish/tank) into 27 circular fiberglass tanks $\left(0.63 \mathrm{~m}^{3}\right)$ supplied with flow-through well-water $\left(24{ }^{\circ} \mathrm{C} ; 4 \mathrm{~L} / \mathrm{min} / \mathrm{tank}\right)$ and ample aeration from a regenerative blower. A subsample of nine randomly selected fish from the original stock was frozen at this time for later determination of initial whole body composition. Each replicate tank of fish was randomly assigned an individually weighed bucket of feed with appropriate diet in order to calculate daily intake. Fish were fed to satiation once daily from 1000 to $1200 \mathrm{~h}$ and feed intake was determined as previously described (Rawles et al., 2012). Fish were individually weighed at four week intervals after withholding feed on the morning of weighing in order to periodically monitor sufficiency of satiation feeding and to estimate feed efficiency at different growth stanzas. Animal care and experimental protocols in this study were carried out according to HKDSNARC Institutional Animal Care and Use Committee policies which conform to USDA/ARS Policies and Procedures 130.4 and 635.1.

\subsection{Fish and tissue sampling}

On the last day of the trial, feed was withheld and all fish were individually weighed. Three fish were randomly selected from each tank for the determination of whole body composition and nutrient retention. Eight additional fish per tank were dissected for body composition indices that included hepatosomatic index (HSI), intraperitoneal fat (IPF) ratio, and muscle ratio (MR). Whole bodies of initial fish and fish from each tank at the end of the trial were homogenized and analyzed as individuals. Individual whole fish were ground into a fine paste using a Retsch knife mill (Grindomix GM300, Retsch GmbH, Haan, Germany) and two 50-100 g aliquots of each homogenate were packed into plastic trays and lyophilized (FreeZone ${ }^{\circledR}$ Triad $^{\mathrm{TM}}$ freeze-drier, Model 7400030, Labconco, Inc., Kansas City, MO). Lyophilized samples were ground in a Thomas-Wiley mill (Model 4, Thomas Scientific Inc., Swedesboro, NJ) to produce a uniform powder for analysis. Two aliquots from each whole body ground homogenate were analyzed and averaged to obtain one representative value per fish. Mean values from three fish per tank (i.e., 9 fish/diet) were averaged to represent the tank value for that analyte.

Because test diets contained a high level of soybean meal (45\%), intestine was collected for the histological assessment of enteritis using similar approaches to those previously described (Laporte and Trushenski, 2012; Urán et al., 2008b). Six fish per diet from diets D3, D5, D7, and D9 were obtained by removing two fish from each of the three replicate tanks for that diet and intestinal portions, approximately $1 \mathrm{~cm}$ in length, of the proximal and distal intestine were collected. After removal, tissues were immediately fixed in Davidson's solution (ENG Scientific, Clifton, New Jersey, USA) for 24 h. Fixed tissues were rinsed with water and stored in 50\% isopropanol until processing. Stored tissues were dehydrated through a graded series of isopropanol, cleared in Citri-Solv (Fisher Scientific, Pittsburgh, Pennsylvania, USA) and embedded in Paraplast Plus (Oxford Labware, St. Louis, Missouri, USA) with a Leica TP1020 tissue processor and a Leica EG1160 sample preparation station (Leica Microsystems, Buffalo Grove, IL). Intestinal segments were serially sectioned (transverse orientation; 4-6 $\mu \mathrm{m}$ thick) with a Leica RM2135 microtome and stained with hematoxylin and eosin (Stevens and Wilson, 1996). Three sections of both the proximal 
Table 2

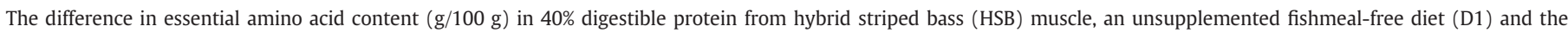
analyzed levels ( $\mathrm{g} / 100-\mathrm{g}$ diet) of amino acids in the respective test diets.

\begin{tabular}{|c|c|c|c|c|c|c|c|c|c|c|c|c|}
\hline \multirow[t]{2}{*}{ Amino acid } & \multirow[t]{2}{*}{ HSB muscle ${ }^{1}$} & \multirow[t]{2}{*}{ Diet $\mathrm{D} 1^{2}$} & \multirow[t]{2}{*}{$\%$ difference } & \multicolumn{9}{|c|}{ Analyzed composition $^{1}$} \\
\hline & & & & D1 & D2 & D3 & D4 & D5 & D6 & D7 & D8 & D9 \\
\hline Arg & 4.12 & 3.11 & -24.5 & 2.26 & 2.20 & 2.20 & 2.19 & 2.07 & 2.37 & 2.25 & 2.11 & 2.43 \\
\hline His & 1.31 & 0.88 & -32.8 & 0.87 & 1.00 & 0.92 & 0.86 & 0.77 & 0.91 & 0.88 & 0.85 & 0.95 \\
\hline Ile & 1.87 & 1.63 & -12.8 & 1.27 & 1.27 & 1.24 & 1.32 & 1.31 & 1.37 & 1.30 & 1.31 & 1.36 \\
\hline Leu & 3.02 & 3.40 & 12.5 & 3.48 & 3.51 & 3.48 & 3.53 & 3.54 & 3.51 & 3.45 & 3.46 & 3.53 \\
\hline Lys & 3.47 & 1.84 & -47.0 & 1.93 & 1.78 & 2.23 & 2.78 & 3.26 & 3.14 & 3.51 & 5.10 & 6.44 \\
\hline Met & 1.32 & 0.57 & -56.8 & 0.38 & 0.86 & 0.92 & 0.97 & 0.97 & 1.03 & 0.94 & 0.99 & 1.01 \\
\hline Phe & 1.68 & 1.91 & 13.7 & 1.78 & 1.80 & 1.76 & 1.84 & 1.81 & 1.93 & 1.82 & 1.81 & 1.90 \\
\hline Thr & 2.33 & 1.44 & -38.2 & 1.44 & 2.31 & 2.11 & 2.07 & 2.01 & 2.26 & 2.14 & 2.03 & 2.37 \\
\hline Trp & 0.40 & 0.38 & -5.0 & n.d. ${ }^{3}$ & n.d. & n.d. & n.d. & n.d. & n.d. & n.d. & n.d. & n.d. \\
\hline Val & 2.10 & 1.78 & -15.5 & 1.66 & 1.71 & 1.63 & 1.64 & 1.63 & 1.75 & 1.66 & 1.62 & 1.74 \\
\hline
\end{tabular}

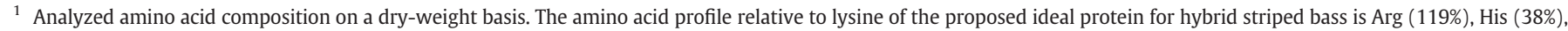
Ile (54\%), Leu (87\%), Lys (100\%), Met + Cys (38\%), Phe + Tyr (48\%), Thr (67\%), Trp (12\%), Val (61\%).

2 Predicted available amino acid levels based on analysis and availability coefficients obtained in prior digestibility trials (Barrows et al., 2011).

3 n.d., not determined.

and distal intestine per fish were blindly evaluated for lesions associated with enteritis.

\subsection{Diet and tissue chemical analyses}

Proximate composition of diets and fish was determined according to standard methods (AOAC, 2005; AOCS, 2009). Briefly, moisture was determined after drying in a convection oven (Isotemp 750F, Fisher Scientific, Hanover Park, IL). Protein $(\mathrm{N} \times 6.25)$ was determined by the Dumas method using a LECO nitrogen analyzer (FP428, LECO Corporation, St. Joseph, MI). Total energy was determined by isoperibol bomb calorimetry (Parr1281, Parr Instrument Company Inc., Moline, IL). Lipid in diets and ingredients was determined by gravimetric quantification following hydrolysis in $3 \mathrm{~N} \mathrm{HCl}$ and petroleum ether extraction (AOCS, 2009; Method AM 5-04) in an ANKOM XT15 lipid extractor (ANKOM Technology, Inc., Macedon, NY). Tissue lipids were similarly determined without the hydrolysis step. Diet and tissue samples were also subjected to acid hydrolysis according to Rayner (1985) without the addition of thioglycollic acid followed by amino acid analysis according to the methods of Henderson et al. (2006) on a high-performance liquid chromatography system (HP1100; Agilent Technologies, Wilmington, DE) equipped with a reversed-phase analytical column (Agilent Zorbax AAA $3.0 \times 150 \mathrm{~mm}, 3.5 \mu \mathrm{m}$ ) and fluorescence detector (Hewlett-Packard G1321-A).

\subsection{Calculations and statistical analysis}

Weight gain $(\%)=\left(\mathrm{W}_{\mathrm{f}}-\mathrm{W}_{\mathrm{i}}\right) * 100 / \mathrm{W}_{\mathrm{i}}$

Average daily intake, $\mathrm{ADI}(\%)$

$=\mathrm{g}$ dry feed consumed $/\left(\left(\mathrm{W}_{\mathrm{f}}-\mathrm{W}_{\mathrm{i}}\right) / 2\right) /$ culture days $* 100$.

Feed efficiency, $\mathrm{FE}=\mathrm{g}$ weight gained/g dry feed consumed;

Lys intake(mg Lys/fish/day)

$=\left(\mathrm{g}\right.$ dry feed consumed $\left.\mathrm{x}[\text { Lys }]_{\text {diet }}\right) /$ fish number/culture days $\mathrm{x} 1000$;

Protein accretion(mg protein/fish/day)

$=\left(\mathrm{W}_{\mathrm{f}}[\mathrm{CP}]_{\mathrm{f}}-\mathrm{W}_{\mathrm{i}}[\mathrm{CP}]_{\mathrm{i}}\right) /$ fish number/culture days $\mathrm{x} 1000$;

Hepatosomatic index, $\mathrm{HSI}(\%)=($ liver mass x 100) $/$ fish mass;

Intraperitoneal fat, $\operatorname{IPF}(\%)=(\operatorname{IPF}$ mass $* 100) /$ fish mass;

Muscle ratio, $\operatorname{MR}(\%)=($ fillet with rib mass $* 100) /$ fish mass;
Protein, energy, or amino acid retention efficiency(RE)

$=($ protein, energy, or amino acid gain $\mathrm{x} 100)$

$\div$ (protein, energy, or amino acid fed);

where $\mathrm{W}_{\mathrm{f}}$ is the mean final fish weight $\left(\mathrm{g}\right.$ ) after 84 days and $\mathrm{W}_{\mathrm{i}}$ is the mean initial fish weight $(\mathrm{g})$; [ $[\mathrm{Lys}]_{\text {diet }}$ is the lysine concentration in the diet; $[\mathrm{CP}]_{\mathrm{f}}$ and $[\mathrm{CP}]_{\mathrm{i}}$ are the crude protein concentrations in the final and initial fish, respectively.

Response data were subjected to polynomial regression in PROC REG and nonlinear regression in PROC NLIN of SAS version 9.1.3 (SAS Institute, Inc., Cary, NC) to fit the most parsimonious model (Ratkowski, 1990) of response with respect to analyzed concentrations of Lys in the test diets. Responses to the unsupplemented negative control diet (D1) were used for qualitative comparison and were not included in the regression analysis. Individual tank data $(n=24)$ from diets D2-D9 were used in all regressions except protein accretion with respect to lysine intake in which diet means $(n=8)$ were modeled. Parsimony was achieved by selecting the significant model $(p \leq 0.05)$ with the lowest mean square error (MSE) and highest adjusted $R^{2} \geq 0.25$. The adjusted $R^{2}$ accounts for differences in model degrees of freedom due to more or less observations and/or unknown parameters being estimated and allows unbiased comparison of regression fits among model types. The adjusted $\mathrm{R}^{2}$ was calculated according to Kvalseth (1985) as follows:

Adjusted $\quad \mathrm{R}^{2}=1-\left\{\left[1-S S_{\text {reg }} / S S_{\text {cor }}\right] \quad[(n-1) /(n-m-1)]\right\}$, where $S S_{\text {reg }}$ is the regression sum of squares, $S S_{\text {cor }}$ is the corrected total sum of squares, $n$ is the number of observations, and $m$ is the number of unknown parameters being estimated for each model type.

Model types applicable to the observed responses included the following:

Linear: $\mathrm{y}=b \mathrm{x}+c$, where $b$ is the slope of the response and $c$ is the intercept on the response (y) axis.

Quadratic: $\mathrm{y}=a \mathrm{x}^{2}+b \mathrm{x}+c$, where $a<0$ is a concave downward function with maximum response and $a>0$ is concave upward with minimum response, $b$ determines the shift in vertex along the dietary Lys concentration ( $\mathrm{x}$ ) axis, $c$ determines the shift in vertex along the response $(\mathrm{y})$ axis, and the maximum or minimum response $\left(\mathrm{y}_{\max , \min }\right)$ is defined as $-b / 2 a$.

Cubic: $\mathrm{y}=z \mathrm{x}^{3}+a \mathrm{x}^{2}+b \mathrm{x}+c$, where the local minima or maxima $\mathrm{y}$-response is defined as $y=\frac{\left(-a \pm \sqrt{a^{2}-3 z b}\right)}{3 z}$ when the function is not monotonic. When monotonic, i.e., no local maxima or minima, the point of inflection along the $\mathrm{x}$-axis defines the dietary Lys concentration 
Table 3

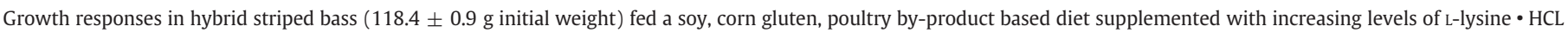
for 12 weeks. Values are least squares means of $N=3$ replicate tanks of fish per diet Lys level.

\begin{tabular}{|c|c|c|c|c|c|c|c|c|}
\hline \multirow[b]{2}{*}{$\operatorname{Diet}_{\text {Lys }}^{2}(\mathrm{~g} / 100 \mathrm{~g})$} & \multicolumn{8}{|c|}{ Response variable $^{1}$} \\
\hline & $W_{f}$ & Weight gain & ADI & Lys intake & Protein accretion & FE4 & FE8 & FE12 \\
\hline Basal $^{3}$ & 327.6 & 180.3 & 1.50 & 64.3 & 433.2 & 0.825 & 0.874 & 0.754 \\
\hline 1.78 & 338.0 & 190.3 & 1.41 & 57.1 & 454.2 & 0.931 & 0.944 & 0.822 \\
\hline 2.23 & 348.5 & 188.9 & 1.40 & 73.2 & 472.1 & 0.898 & 0.934 & 0.826 \\
\hline 2.78 & 338.6 & 192.3 & 1.44 & 91.2 & 468.5 & 0.899 & 0.935 & 0.809 \\
\hline 3.14 & 356.5 & 197.8 & 1.43 & 107.6 & 481.9 & 0.929 & 0.961 & 0.829 \\
\hline 3.26 & 348.6 & 199.9 & 1.42 & 106.9 & 502.4 & 0.967 & 0.945 & 0.836 \\
\hline 3.51 & 338.9 & 197.3 & 1.45 & 114.9 & 477.2 & 0.926 & 0.946 & 0.816 \\
\hline 5.10 & 358.1 & 202.9 & 1.43 & 172.9 & 509.4 & 0.963 & 0.945 & 0.844 \\
\hline 6.44 & 368.6 & 197.0 & 1.70 & 267.1 & 498.0 & 0.865 & 0.815 & 0.695 \\
\hline Pooled SE & 7.1 & 5.9 & 0.02 & 4.4 & 11.3 & 0.028 & 0.020 & 0.016 \\
\hline \multicolumn{9}{|l|}{ Regression analysis } \\
\hline Model $^{4}$ & Linear & Cubic & Cubic & Cubic & Quadr & Cubic & Cubic & Cubic \\
\hline $\mathrm{R}^{2}$ & 0.325 & 0.863 & 0.849 & 0.989 & 0.731 & 0.284 & 0.695 & 0.767 \\
\hline $\operatorname{Pr}>\mathrm{F}$ & 0.002 & 0.033 & $<0.001$ & $<0.001$ & 0.038 & 0.077 & $<0.001$ & $<0.001$ \\
\hline \multicolumn{9}{|l|}{ Parameter estimates $^{5}$} \\
\hline $\mathrm{z}$ & - & -0.450 & 0.014 & 2.254 & - & -0.008 & -0.006 & -0.008 \\
\hline $\mathrm{a}$ & - & 3.969 & -0.154 & -22.581 & -3.541 & 0.080 & 0.060 & 0.088 \\
\hline b & 6.999 & -5.665 & 0.513 & 104.461 & 38.725 & -0.251 & -0.180 & -0.280 \\
\hline c & 323.34 & 188.91 & 0.888 & -71.065 & 397.675 & 1.156 & 1.107 & 1.095 \\
\hline R99 & - & 4.13 & 3.55 & Monotonic $^{6}$ & 4.28 & 4.15 & 3.40 & 3.92 \\
\hline R95 & - & 2.65 & $2.71^{7}$ & Monotonic & 2.80 & 2.93 & $2.80^{8}$ & 2.44 \\
\hline
\end{tabular}

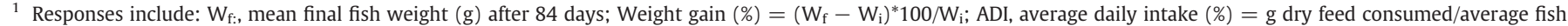

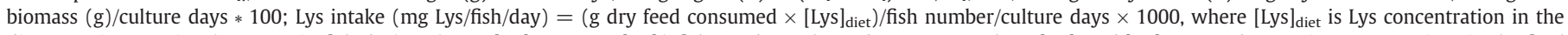

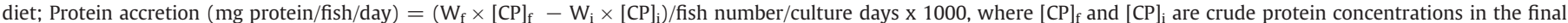
and initial fish, respectively; FEx: feed efficiency up to week $x=\mathrm{g}$ weight gained/g dry feed consumed; Diet Lys level effect considered significant at $p \leq 0.05$ and $\mathrm{R}^{2} \geq 0.25$.

2 Diet Lys concentration (analyzed) on a dry-weight basis.

${ }^{3}$ Negative basal diet, - Basal (D1), was not supplemented with Lys, Met, or Thr and measured $1.93 \mathrm{~g}$ Lys/100 g diet from intact protein. Responses to the negative basal diet were not included in the regression analyses.

4 Model types are linear $(\mathrm{y}=b \mathrm{x}+c)$, quadratic (quadr: $\left.\mathrm{y}=a \mathrm{x}^{2}+b \mathrm{x}+c\right)$, 3rd order polynomial (cubic: $\left.\mathrm{y}=z \mathrm{x}^{3}+a \mathrm{x}^{2}+b \mathrm{x}+c\right)$, or negative exponential (neg exp: $\mathrm{y}=a+c \mathrm{e}^{-b \mathrm{x}}$ for decreasing functions). $N R$ denotes "no relationship", i.e., $p>0.05$ and $\mathrm{R}^{2}<0.25$ for any regression relationship explored.

${ }^{5}$ Model parameters as defined in footnote ${ }^{4}$ above. Plateau values R99 and R95 are the dietary lysine levels ( $\mathrm{g}$ Lys/100 g diet) required to reach 99 or $95 \%$ of the minimum or maximum response, respectively.

6 Monotonic function, i.e., no local maxima or minima.

7 Lower limit of estimation corresponds to a y-value that is $98 \%$ (R98) of the minimum average daily feed intake (ADI).

${ }^{8}$ Lower limit of estimation corresponds to a y-value that is 97.6\% (R97.6) of the maximum feed efficiency at 8 weeks (FE8).

where the response curve changes from decreasing to increasing slope, or vice versa, and is calculated as $\mathrm{x}=-2 a / 6 z$.

Negative exponential: $\mathrm{y}=a+c \mathrm{e}^{-b \mathrm{x}}$, where $a$ is the minimum asymptotic response value, $c$ is the theoretical maximum y-response, and $b$ defines the steepness of the response curve.

In the case of nonlinear, non-monotonic relationships, the plateau value R100, i.e., the dietary lysine level (x) required to reach $100 \%$ of the minimum or maximum $y$-response was determined by solving for $x$ once $y_{\max }$ min was known. Similarly, the plateau values R95 and R99 - the dietary lysine levels (x) required to reach $95 \%$ or $99 \%$ of the minimum or maximum y-response, respectively - were calculated either iteratively or analytically (Rodehutscord and Pack, 1999 ) to provide, where possible, $95 \%$ and $99 \%$ confidence intervals about the R100 value.

\section{Results}

\subsection{Growth and feed performance}

With the exception of final fish weights and protein accretion, hybrid striped bass growth metrics were best modeled by cubic functions of Lys concentration in the diets (Table 3). Mean final fish weights ranged from $328 \mathrm{~g}$ to $369 \mathrm{~g}$ with corresponding gains of $180 \%$ to $203 \%$ of initial weight (Table 3 ); therefore, some fish tripled their weight after 84 days of culture. There were no mortalities in the trial, although one fish was removed from the study after it escaped its tank. Final weight increased as a linear function ( $p=$ $\left.0.002 ; R^{2}=0.325\right)$, whereas weight gain increased as a cubic function $\left(p=0.033 ; \mathrm{R}^{2}=0.863\right)$ of Lys level in the supplemented (D2-D9) diets (Fig. 1, top panel). Final weights and weight gains of fish fed the unsupplemented negative control diet (D1) were approximately $3 \%$ and $5 \%$ lower, respectively, than the poorest performing supplemented diets, but $12.5 \%$ lower than the best performing supplemented diets. Weight gains were optimized between 2.7 and $4.1 \mathrm{~g}$ Lys/100 g diet to achieve R95 and R99 plateau values, respectively. Although daily feed intake fluctuated widely from $1 \%$ to over $5 \%$ of body weight on a day-to-day basis (data not shown), ADI ranged more narrowly from $1.4 \%$ to $1.7 \%$ of average body weight as a cubic function of dietary Lys level. ADI was 95\% and 99\% of minimum at 2.7 and $3.6 \mathrm{~g}$ Lys/ $100 \mathrm{~g}$ diet, respectively. Lysine intake $(\mathrm{mg} /$ fish/day) fit a monotonic cubic function $\left(p<0.001 ; \mathrm{R}^{2}=0.989\right)$ of diet concentration and increased from $57 \mathrm{mg} / \mathrm{fish} /$ day in the lowest supplemented diet (D2) to $267 \mathrm{mg} /$ fish/day at the highest level of Lys supplementation (D9). Feed efficiencies after 12 weeks of feeding (FE12) ranged from 0.695 to 0.844 and were lower than those observed after only 4 weeks (FE4) and 8 weeks (FE8) of feeding (Table 3). The Lys requirement to achieve 95\% and 99\% of maximum feeding efficiency (Table 3 ) was higher in smaller fish at 4 weeks of feeding ( 2.9 to $4.2 \mathrm{~g}$ Lys/100 g diet, respectively) than that required for larger fish after 12 weeks of feeding (2.4 and $3.9 \mathrm{~g}$ Lys/100 g diet, respectively; Fig. 1., bottom panel). Protein accretion was lowest in fish fed the D1 diet at $433 \mathrm{mg}$ protein/fish/day and $5 \%$ lower than the lowest observed protein gain ( $454 \mathrm{mg} / \mathrm{fish} /$ day) in fish fed the supplemented basal diet (D2). Protein accretion increased 

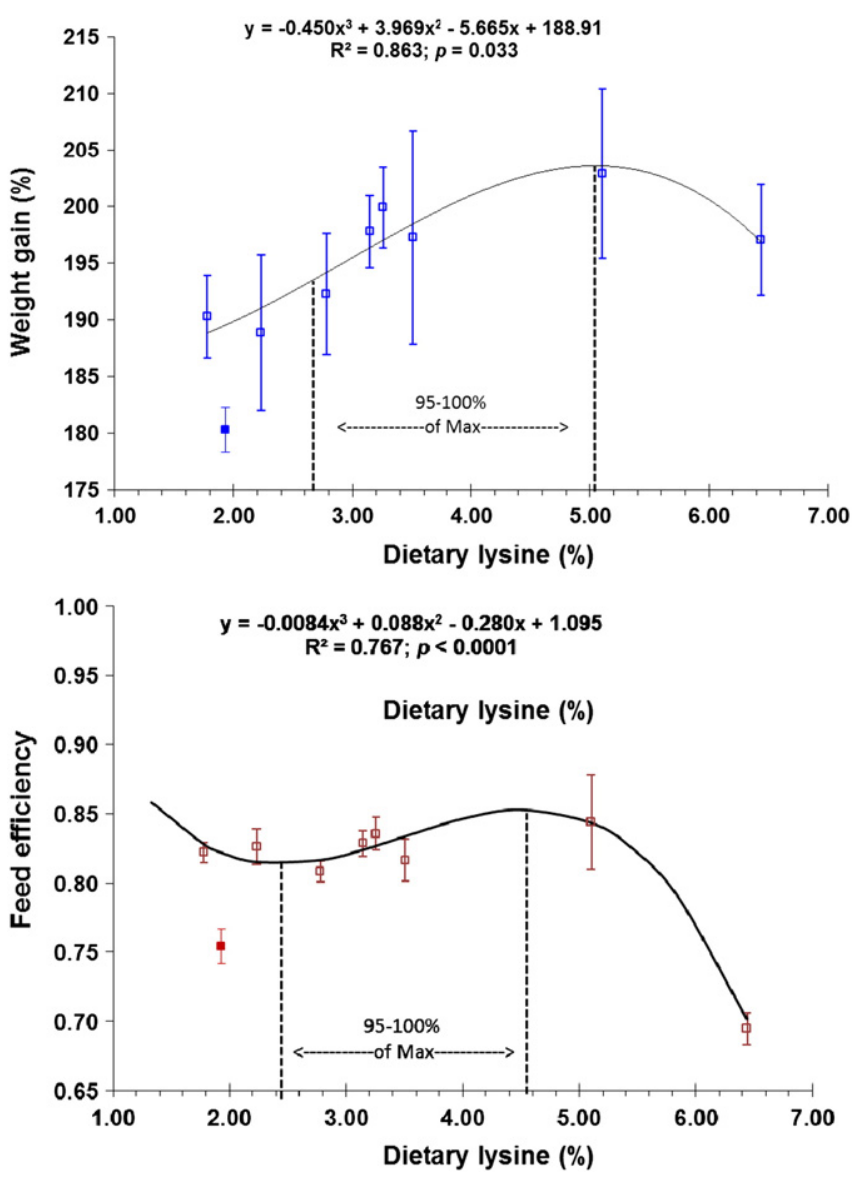

Fig. 1. Mean ( \pm SE) weight gain (top panel) and feed efficiency (bottom panel) in hybrid striped bass fed a fishmeal-free diet supplemented with Met and Thr and increasing levels of Lys for 12 weeks. Open-square ( $\square$ ) means are responses to the supplemented diets (D2-D9); closed square ( $\square$ ) mean is response to the unsupplemented diet (D1; not included in regression fit).

as a quadratic function of both diet Lys level (Table 3) and mean Lys intake (Fig. 2). The Lys requirement to reach $95 \%$ and $99 \%$ of maximum protein accretion was 2.8 and $4.3 \mathrm{~g}$ Lys/100 g diet, respectively (Table 3), and corresponded to 103 and $158 \mathrm{mg}$ Lys/fish/day, respectively (Fig. 2).

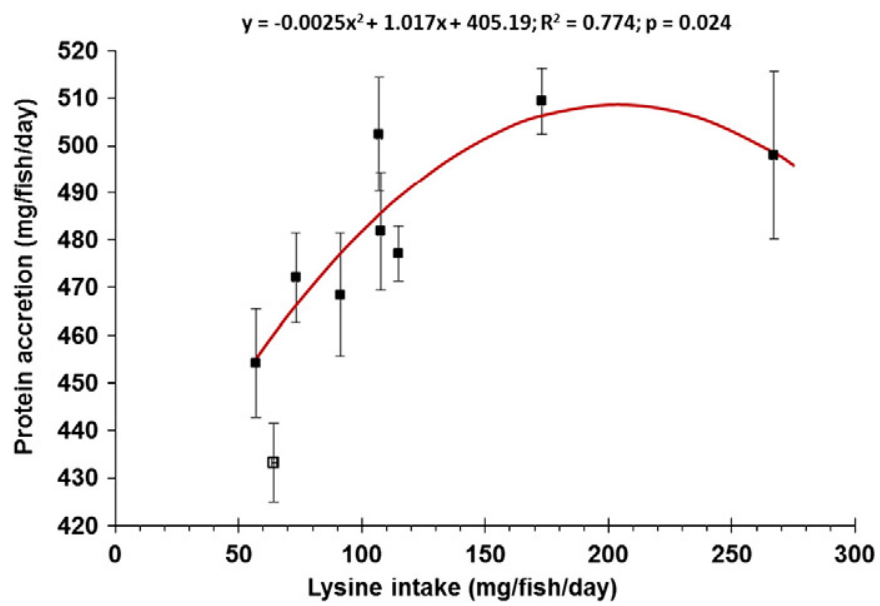

Fig. 2. Mean $( \pm S E)$ protein accretion $(\mathrm{mg} / \mathrm{fish} /$ day) in relation to mean Lys intake ( $\mathrm{mg} /$ fish/day) in hybrid striped bass fed a fishmeal-free diet supplemented with Met and Thr and increasing levels of Lys for 12 weeks. Open-square ( $\square$ ) mean is response to the unsupplemented diet (D1; not included in regression fit) and closed square ( $\mathbf{\square})$ means are responses to the supplemented diets (D2-D9). The Lys requirement to reach 95 and $99 \%$ of maximum protein accretion is 103 and $158 \mathrm{mg}$ Lys/fish/day, respectively.

\subsection{Body composition and composition indices}

Whole body composition appeared unresponsive to diet Lys level (Table 4$)$. On a fresh-weight basis, mean $( \pm \mathrm{SE})$ whole body protein (\%), lipid (\%), energy ( $\mathrm{kcal} / \mathrm{kg}$ ) and moisture (\%) were $41.3 \pm 0.4$, $20.1 \pm 0.3,4163 \pm 15$, and $69.5 \pm 0.2$, respectively. On the other hand, body condition indices were best fit by 3rd order polynomials $\left(\mathrm{R}^{2}=0.41-0.44\right)$ in response to diet Lys concentration (Table 4). Higher dietary Lys was required to reduce liver size (HSI) to within $95 \%$ to $99 \%$ of minimum at 4.8 to $5.2 \mathrm{~g}$ Lys $/ 100 \mathrm{~g}$ diet, respectively, than to reduce body fat (IPF) at 2.5 to $3.1 \mathrm{~g}$ Lys/100 g diet (Fig. 3, bottom panel), or to maximize muscle ratio at 1.8 to $3.9 \mathrm{~g}$ Lys $/ 100 \mathrm{~g}$ diet (Fig. 3, top panel). Higher IPF was observed in fish fed the unsupplemented basal diet (D1) when compared to those fed the supplemented diets (Fig. 3, bottom panel).

\subsection{Nutrient, energy, and amino acid retention}

Whole body protein, lipid, energy, and EAA retentions were also consistent with cubic functions of dietary Lys level with notable exceptions (Table 5 ). Whole body protein retention was best modeled by a monotonic cubic function $\left(p<0.001 ; \mathrm{R}^{2}=0.800\right.$; adj $\mathrm{R}^{2}=0.770$; MSE $=2.46$ ). The cubic inflection point at $\mathrm{x}=3.0 \mathrm{~g}$ Lys $/ 100 \mathrm{~g}$ of diet denotes the dietary lysine concentration after which protein retention decreases more rapidly, i.e., diminishing returns. Lower Lys requirements were found to maximize lipid retention (2.2-3.5 g Lys/100 g

Table 4

Whole body composition and composition indices of hybrid striped bass $(118.4 \pm 0.9 \mathrm{~g}$ initial weight) fed a soy, corn gluten, poultry by-product based diet supplemented with increasing levels of L-lysine $\cdot \mathrm{HCL}$ for 12 weeks. Values are least squares means of $N=3$ replicate tanks of fish per diet Lys level.

\begin{tabular}{|c|c|c|c|c|c|c|c|}
\hline \multirow[b]{2}{*}{$\operatorname{Diet}_{\text {Lys }}^{2}(\mathrm{~g} / 100 \mathrm{~g})$} & \multicolumn{7}{|c|}{ Response variable $^{1}$} \\
\hline & $\mathrm{CP}$ & Lipid & Energy & Moisture & HSI & IPF & MR \\
\hline Basal $^{3}$ & 17.9 & 9.43 & 1835 & 69.0 & 1.34 & 5.04 & 59.85 \\
\hline 1.78 & 17.9 & 8.62 & 1794 & 70.0 & 1.12 & 4.51 & 60.83 \\
\hline 2.23 & 18.0 & 8.76 & 1846 & 69.5 & 1.33 & 4.13 & 59.46 \\
\hline 2.78 & 18.2 & 9.22 & 1818 & 69.1 & 1.02 & 4.17 & 61.26 \\
\hline 3.14 & 18.3 & 8.79 & 1816 & 69.5 & 1.05 & 4.02 & 62.58 \\
\hline 3.26 & 18.0 & 9.40 & 1875 & 69.2 & 1.31 & 3.79 & 60.74 \\
\hline 3.51 & 18.3 & 8.50 & 1801 & 69.8 & 1.18 & 3.91 & 60.98 \\
\hline 5.10 & 18.3 & 9.44 & 1888 & 68.9 & 0.89 & 3.98 & 62.07 \\
\hline 6.44 & 17.9 & 8.10 & 1780 & 70.1 & 1.03 & 3.71 & 61.64 \\
\hline Pooled SE & 0.18 & 0.56 & 52 & 0.60 & 0.04 & 0.16 & 0.28 \\
\hline \multicolumn{8}{|l|}{ Regression analysis } \\
\hline Model $^{4}$ & $N R$ & $N R$ & $N R$ & $N R$ & Cubic & Cubic & Cubic \\
\hline $\mathrm{R}^{2}$ & - & - & - & - & 0.413 & 0.440 & 0.417 \\
\hline $\operatorname{Pr}>\mathrm{F}$ & - & - & - & - & 0.012 & 0.008 & 0.012 \\
\hline \multicolumn{8}{|l|}{ Parameter estimates 5} \\
\hline $\mathrm{z}$ & - & - & - & - & 0.025 & -0.039 & -0.076 \\
\hline $\mathrm{a}$ & - & - & - & - & -0.299 & 0.508 & 0.813 \\
\hline $\mathrm{b}$ & - & - & - & - & 1.016 & -2.177 & -2.193 \\
\hline c & - & - & - & - & 0.146 & 6.974 & 62.158 \\
\hline R99 & - & - & - & - & 5.15 & 3.11 & 3.94 \\
\hline R95 & - & - & - & - & 4.77 & 2.48 & $1.78^{6}$ \\
\hline
\end{tabular}

1 Whole body composition (fresh-weight basis) and composition indices include $\mathrm{CP}$ : crude protein (\%), Lipid (\%), Energy ( $\mathrm{kcal} / \mathrm{kg}$ ), and Moisture (\%), HSI: hepatosomatic index $(\%)=($ liver mass x 100$) /$ fish mass, IPF: intraperitoneal fat $(\%)=$ (intraperitoneal fat mass * 100)/fish mass, MR: muscle ratio $(\%)=($ fillet with rib mass $* 100) /$ fish mass. Diet LYS level effect was considered significant at $p \leq 0.05$ and $\mathrm{R}^{2} \geq 0.25$.

2 Diet Lys concentration (analyzed) on a dry-weight basis.

3 Negative basal diet, - Basal (D1), was not supplemented with Lys, Met, or Thr and measured $1.93 \mathrm{~g}$ Lys/100 $\mathrm{g}$ diet from intact protein

4 Models are described in Table 3, footnote ${ }^{4}$. NR denotes "no relationship", i.e., $p>0.05$ and $\mathrm{R}^{2}<0.25$ for any regression relationship explored.

${ }^{5}$ Model parameters and plateau levels are defined in Table 3, footnote ${ }^{5}$.

${ }^{6}$ Lower limit of estimation; corresponds to a y-value that is 97\% (R97) of the maximum muscle ratio (MR). 

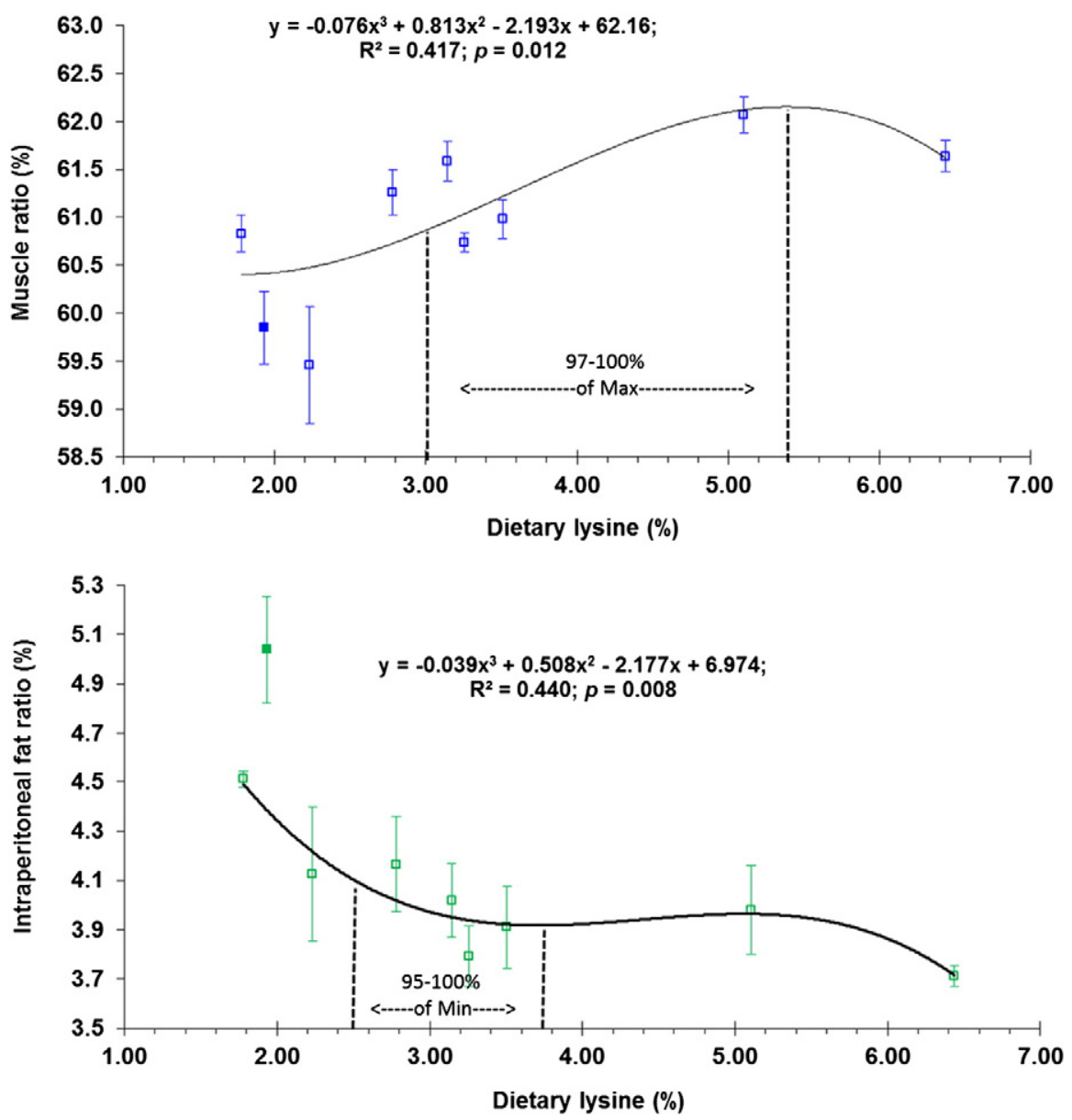

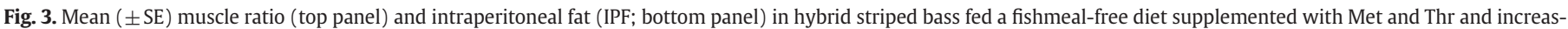

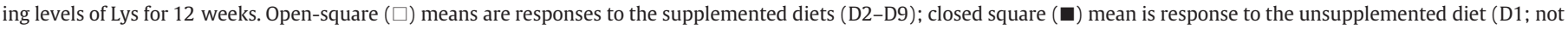
included in regression fit). The lower limit of estimation for muscle ratio corresponds to a y-value that is 97\% (R97) of the maximum muscle ratio (MR).

diet) than to maximize total diet energy retention (3.3-4.1 g Lys/100 g diet).

Retention of Lys decreased exponentially $\left(p<0.001 ; \mathrm{R}^{2}=0.848\right)$ with increasing dietary Lys (Table 5; Fig. 4, top panel). Lysine retention in the unsupplemented basal diet (D1) was $42 \%$ and markedly lower than Lys retention in the supplemented basal diet (D2) at $58 \%$ (Table 5). On the other hand, methionine retention in the supplemented diets decreased in a slow linear $\left(p=0.004 ; \mathrm{R}^{2}=0.314\right)$ fashion (Table 5; Fig. 4, middle panel) and was notably lower, at $23-37 \%$, than the unsupplemented diet at 68\% retention efficiency. Threonine retention was well modeled $\left(p=0.002 ; \mathrm{R}^{2}=0.512\right)$ by a cubic function with R95 and R99 values of 3.7 and $4.3 \mathrm{~g} \mathrm{Lys} / 100 \mathrm{~g}$ diet (Table 5; Fig. 4, bottom panel). Retention of Thr was also higher in the unsupplemented basal diet (36\%) than in the supplemented diets (20-29\%).

Retention of His, on the other hand, responded quadratically to dietary Lys level with 3.1 and $3.7 \mathrm{~g}$ Lys/100 g diet required to reach 95 and $99 \%$ of maximum retention (Table 5; Fig. 5). Histidine retention in the unsupplemented basal diet (28.6\%) was slightly higher than that observed in the Met and Thr supplemented basal diet (27.4\%). Arginine retention was optimized at a lower Lys concentration (2.5$3.8 \mathrm{~g}$ Lys/100 g diet) than that required to optimize branched-chain amino acids (about 3.7-4.5 g Lys/100 g diet). Similar to Lys, the retention of Arg in the unsupplemented basal diet (29\%) was lower than that of the Met and Thr supplemented basal diet (35\%). The retention of Leu and Val in the unsupplemented basal diet was on par with retentions observed in the supplemented basal diet, while the retention of Ile in D1 was slightly lower than that of D2. Retention of Phe appeared unresponsive to dietary Lys concentration (Table 5).

\subsection{Histological evaluation}

Histological evaluation of proximal and distal intestine did not reveal any lesions associated with enteritis in any diet (not shown). Collectively, the intestines examined showed normal intestinal morphology with slender and discrete mucosal folds, well-vacuolated enterocytes, lamina propria of diminutive thickness, and characteristic goblet cell abundance and distribution. Infrequently, small numbers of eosinophilic granular cells were noted in the lamina propria or the submucosa, but the quantity and localization of this cell type was similar among all fish examined.

\section{Discussion}

Different approaches to establishing the essential amino acid (EAA) requirements of cultured moronids have been promulgated. Brown (1995) used the established Lys requirement from Griffin et al. (1992) and the ratio of EAA in whole body HSB to supplement casein-gelatin diets with crystalline amino acids that matched $100 \%$ of the whole body EAA profile. Interestingly, the concentration of Lys in their whole body samples ( $1.41 \mathrm{~g}$ Lys/100 g) was almost identical to the estimated requirement by Griffin et al. (1992). They concluded that refinements were needed to optimize performance of their diets that ranged from $32 \%$ to $40 \%$ crude protein relative to a fishmeal-based diet formulated 
Table 5

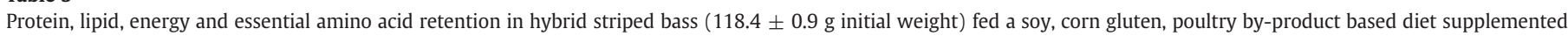
with increasing levels of L-lysine $\cdot$ HCL for 12 weeks. Values are least squares means of $N=3$ replicate tanks of fish per diet Lys level.

\begin{tabular}{|c|c|c|c|c|c|c|c|c|c|c|c|c|}
\hline \multirow[b]{2}{*}{ Diet Lys ${ }^{2}(\mathrm{~g} / 100 \mathrm{~g})$} & \multicolumn{12}{|c|}{ Retention efficiencies $^{1}$} \\
\hline & Protein & Lipid & Energy & Arg & His & Ile & Leu & Lys & Met & Phe & Thr & Val \\
\hline Basal $^{3}$ & 31.6 & 51.4 & 29.9 & 29.0 & 28.6 & 29.9 & 24.5 & 42.3 & 68.3 & 24.1 & 36.1 & 32.4 \\
\hline 1.78 & 32.6 & 49.0 & 31.5 & 34.8 & 27.4 & 32.6 & 24.9 & 57.9 & 36.8 & 26.4 & 23.6 & 32.4 \\
\hline 2.23 & 34.4 & 52.0 & 33.3 & 35.4 & 29.9 & 33.5 & 23.5 & 49.9 & 36.6 & 26.0 & 24.3 & 31.3 \\
\hline 2.78 & 34.7 & 49.3 & 31.0 & 30.5 & 29.1 & 29.4 & 25.1 & 32.1 & 26.0 & 23.2 & 24.7 & 33.1 \\
\hline 3.14 & 32.7 & 51.6 & 31.9 & 31.4 & 33.2 & 30.0 & 26.3 & 29.9 & 33.8 & 25.6 & 26.1 & 33.7 \\
\hline 3.26 & 32.2 & 54.0 & 33.3 & 38.6 & 40.0 & 33.8 & 26.1 & 33.0 & 33.6 & 27.4 & 28.3 & 36.2 \\
\hline 3.51 & 32.2 & 48.1 & 30.8 & 36.0 & 32.5 & 30.6 & 23.6 & 32.1 & 35.0 & 25.2 & 24.3 & 30.7 \\
\hline 5.10 & 31.9 & 52.0 & 34.1 & 33.7 & 34.5 & 34.4 & 28.9 & 20.2 & 29.9 & 26.9 & 29.0 & 38.3 \\
\hline 6.44 & 24.3 & 38.3 & 25.6 & 24.7 & 26.1 & 25.0 & 21.7 & 13.8 & 23.2 & 23.1 & 20.4 & 28.1 \\
\hline Pooled SE & 0.702 & 4.08 & 1.48 & 2.33 & 2.10 & 1.30 & 1.04 & 2.67 & 2.55 & 1.74 & 1.20 & 1.53 \\
\hline \multicolumn{13}{|l|}{ Regression analysis } \\
\hline Model $^{4}$ & Cubic & Cubic & Cubic & Cubic & Quadr & Cubic & Cubic & Neg exp & Linear & $N R$ & Cubic & Cubic \\
\hline $\mathrm{R}^{2}$ & 0.800 & 0.352 & 0.481 & 0.405 & 0.412 & 0.539 & 0.440 & 0.848 & 0.314 & - & 0.512 & 0.400 \\
\hline $\operatorname{Pr}>\mathrm{F}$ & $<0.001$ & 0.031 & 0.004 & 0.014 & 0.004 & 0.001 & 0.008 & $<0.001$ & 0.004 & - & 0.002 & 0.015 \\
\hline \multicolumn{13}{|l|}{ Parameter estimates $^{5}$} \\
\hline $\mathrm{z}$ & -0.213 & -0.577 & -0.500 & -0.525 & - & -0.739 & -0.530 & - & - & - & -0.472 & -0.705 \\
\hline $\mathrm{a}$ & 1.918 & 5.598 & 5.336 & 5.412 & -1.683 & 8.361 & 5.760 & 12.730 & - & - & 4.697 & 7.565 \\
\hline b & -5.782 & -16.127 & -17.269 & -17.256 & 13.806 & -29.085 & -18.295 & 0.611 & -2.431 & - & -12.851 & -23.572 \\
\hline c & 38.850 & 64.370 & 49.090 & 51.340 & 7.300 & 62.920 & 42.150 & 134.500 & 40.440 & - & 34.530 & 54.480 \\
\hline R99 & Monotonic $^{6}$ & 3.52 & 4.13 & 3.81 & 3.65 & 4.41 & 4.50 & 11.5 & - & - & 4.30 & 4.47 \\
\hline R95 & Monotonic & 2.17 & 3.28 & 2.51 & 3.07 & 3.77 & 3.93 & 8.76 & - & - & 3.73 & 3.90 \\
\hline
\end{tabular}

${ }^{1}$ Retention efficiency $=$ (g or cal gain $\mathrm{x} 100$ )/(g or cal fed). Diet Lys level effect considered significant at $p \leq 0.05$ and $\mathrm{R}^{2} \geq 0.25$.

2 Diet Lys concentration (analyzed) on a dry-weight basis.

3 Negative basal diet, - Basal (D1), was not supplemented with Lys, Met, or Thr and measured $1.93 \mathrm{~g}$ Lys/100 g diet from intact protein

4 Models are described in Table 3, footnote ${ }^{4}$. NR denotes "no relationship", i.e., $p>0.05$ and $\mathrm{R}^{2}<0.25$ for any regression explored.

5 Model parameters and plateau levels are defined in Table 3, footnote 5.

${ }^{6}$ Monotonic function, i.e., no local maxima or minima; protein retention efficiency inflection point at $x=3.00 \mathrm{~g}$ Lys $/ 100 \mathrm{~g}$ diet.

for salmonids at $36 \%$ crude protein. Twibell et al. (2003) extended the previous results using the same technique and assumptions of Brown (1995) by supplementing 35\% crude protein casein-gelatin diets with crystalline amino acids to match $100 \%$ to $140 \%$ of the whole body EAA profile of HSB. They concluded that $120 \%$ of the whole body EAA profile, which included $1.7 \mathrm{~g}$ Lys/100 g diet, was required to optimize performance of their semi-purified diets relative to a fishmeal-based diet. Moreover, higher levels of Thr, Ile, and Trp were required than those suggested by the whole body ratios. Small and Soares (1998) used a mix of practical ingredients, the EAA profile of striped bass fillet, and supplemental lysine HCL to form a series of commercial style diets with varying levels of Lys (1.57-2.65 g/100 g diet). Their subsequent requirement estimate for striped bass based on non-linear regression ( $2.2 \mathrm{~g}$ Lys/100 g diet) exceeded the original requirement estimate by $57 \%$. It is important to note that crude protein in the practical diets tested by Small and Soares (1998) ranged from 31\% to $42 \%$ and an average amino acid availability of $85 \%$ was assumed; therefore, digestible protein (DP) probably ranged from $26 \%$ to $36 \%$.

In contrast, our previous work in both hybrid striped bass (Gaylord and Rawles, 2005; Rawles et al., 2009, 2011) and rainbow trout (Gaylord and Barrows, 2009) suggests that the lysine requirement of these carnivorous species may be as high as 3.5-3.9 g Lys/g diet in commercial formulas when reliable ingredient composition and nutrient availability data are used for formulation and diet DP is targeted at $40 \%$ to $45 \%$, respectively. The current R95 to R100 parameter estimates generally support our previous findings that the dietary level of lysine required to optimize typical growth metrics in hybrid striped bass fed commercial diets is near the level suggested by the muscle profile at the target DP. Therefore, though Lys was not first limiting in our test diets and imbalances in amino acids in some of the test diets potentially exist, it appears that ideal protein theory sufficiently predicts first-limiting amino acids and optimum Lys supplementation needed to improve performance of a fishmeal-free diet for hybrid striped bass when combined with reliable nutrient availability data. It is also important to point out that fish in this study accepted all test diets extremely well, which is confirmed by exemplary growth since fish more than tripled their weight in 12 weeks. Although average daily intake (ADI) decreased as a cubic function of increasing Lys in the diet at lower levels of Lys supplementation, ADI dramatically increased to $1.7 \%$ at the highest level of supplementation (Table 3) suggesting that intake was not a reflection of poorer palatability but of higher efficiency in the region of dietary Lys close to the optimum where weight gain, feed efficiency, and protein accretion were also maximized. The dramatic increase in feed intake at the highest diet Lys concentration may reflect a compensatory feeding response to a highly imbalanced diet as suggested by Yamamoto et al. (2001). Finally, even though the relationship between feed efficiency and diet Lys concentration at 4 weeks was not exceptionally strong $\left(\mathrm{R}^{2}=0.28 ; p=\right.$ 0.08 ), there was an evident decline in Lys required to maximize feed efficiency from 4 weeks (R95 $=2.9 \mathrm{~g}$ Lys $/ 100 \mathrm{~g}$ diet), to 8 weeks $(2.8 \mathrm{~g}$ Lys/100 g diet), to 12 weeks (2.4 g Lys/100 g diet) of growth with commiserate increases in the statistical significance $(p<0.0001)$ and correlations of the relationships at weeks $8\left(R^{2}=0.70\right)$ and $12\left(R^{2}=0.77\right)$, which are consistent with our current understanding of the higher nutrient requirements of younger, faster growing animals.

In contrast to some reports, we did not find a difference in Lys requirements for maximizing muscle ratio as opposed to growth when several works reported higher Lys requirements for muscle mass as opposed to weight gain in poultry (Hickling et al., 1990; Moran and Bilgili, 1990) and fish. For example, Espe et al. (2007) found a lower level of Lys ( $3.2 \mathrm{~g}$ Lys/16 $\mathrm{g} \mathrm{N}$ ) required to maximize weight gain as opposed to protein accretion ( $5 \mathrm{~g}$ Lys/16 $\mathrm{g} \mathrm{N}$ ) in Atlantic salmon Salmo salar relative to a fishmeal control diet, while Zhou et al. (2010) found higher levels of Arg were required to maximize other essential amino acid retentions in black sea bream Sparus macrocephalus than those found to maximize growth. Most likely, our lack of differences in Lys requirements for maximizing muscle ratio vis-à-vis growth are a result of balancing dietary amino acids to the ideal muscle levels, whereas, the studies cited above used NRC poultry, fishmeal, or whole body amino acid levels as their reference levels. 

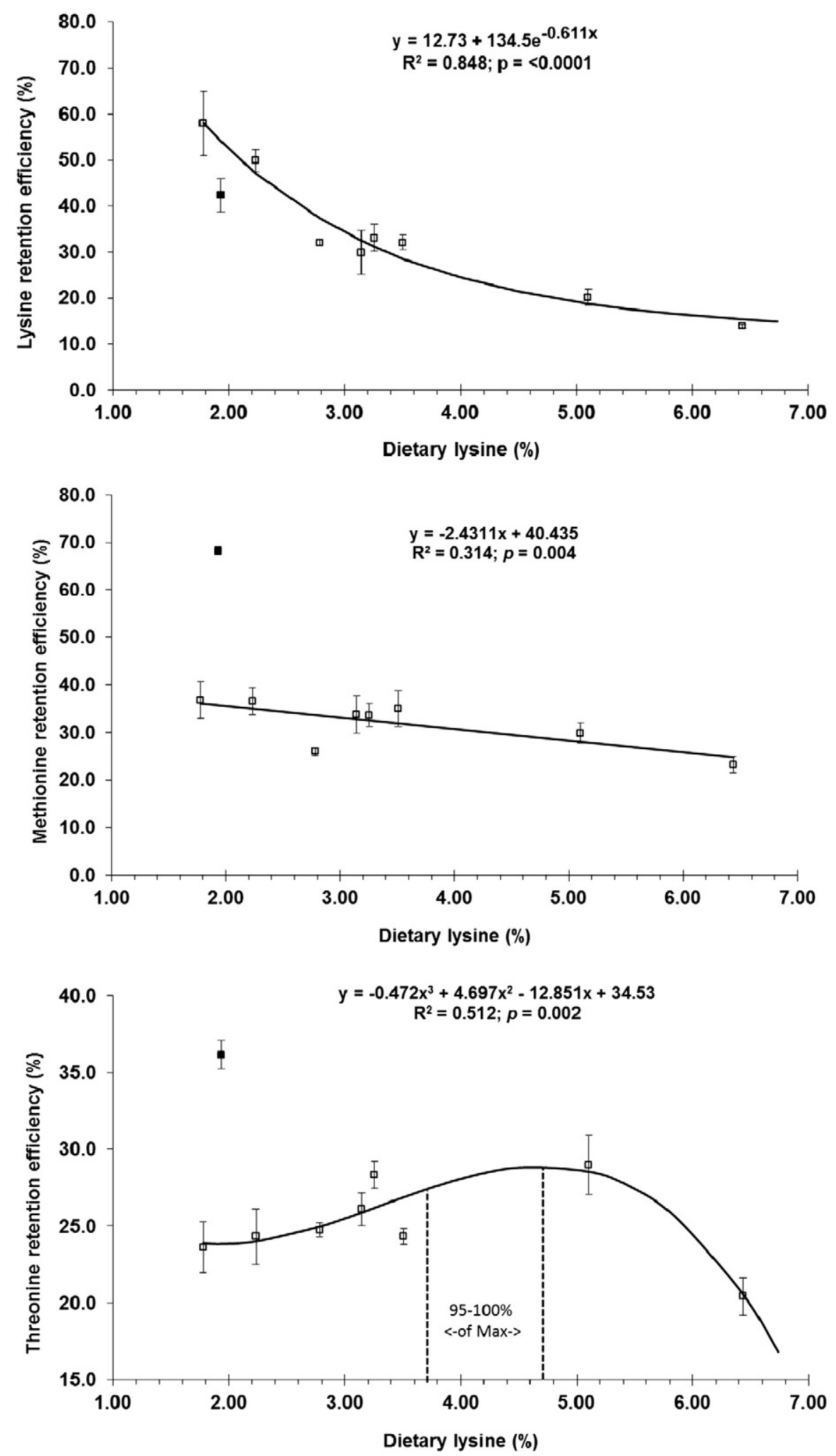

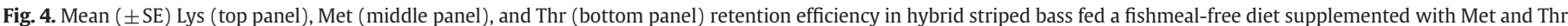

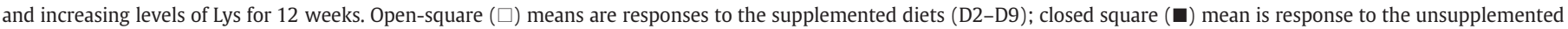
diet (D1; not included in regression fit).

We also found that HSI decreased with increasing dietary Lys, and that a higher level of Lys than that in the muscle profile was required to minimize liver size as opposed to maximize growth. Espe et al. (2007, 2008) and Gaylord and Barrows (2009) noted higher liver weight relative to body weight at deficient levels of the amino acids of interest, presumably from excess energy deposition as suggested by Rathore et al. (2010), while Espe et al. (2007) found a relatively high level of Lys (4.1-4.9 g Lys/16 $\mathrm{g} \mathrm{N}$ ) required to reach a stable liver size when no significant differences in weight gain were observed for the same range of dietary Lys concentrations. 


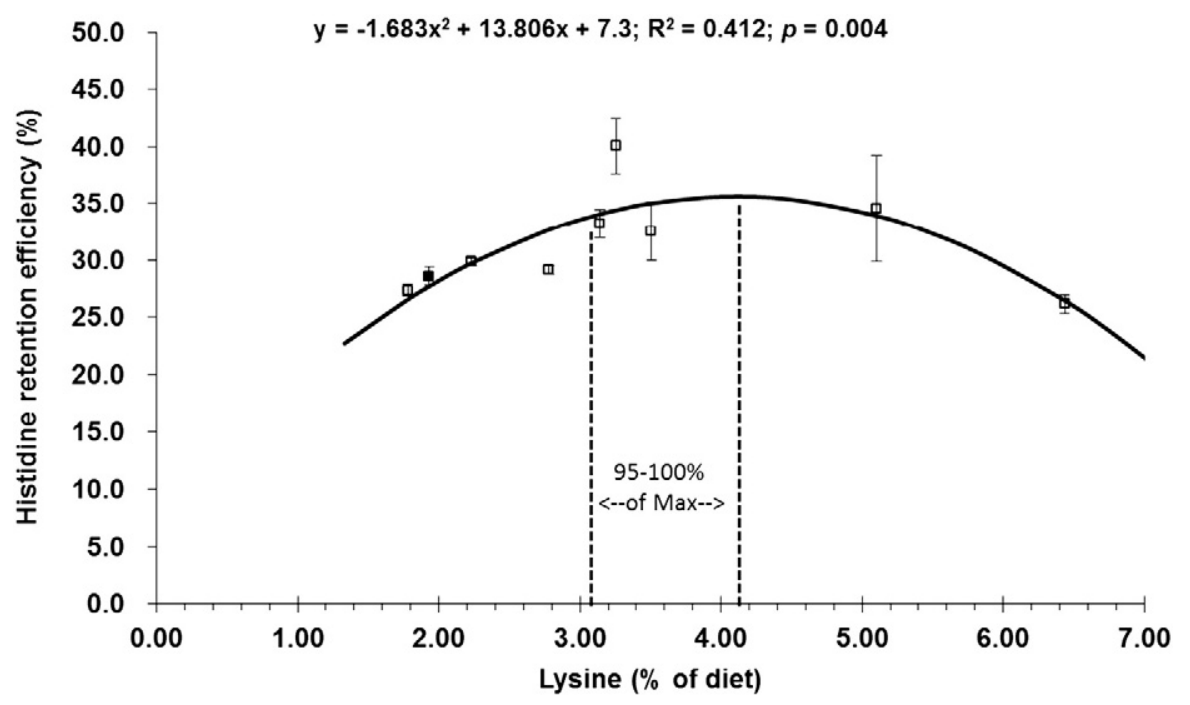

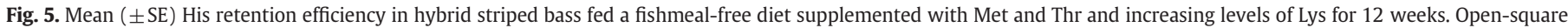
$(\square)$ means are responses to the supplemented diets (D2-D9); closed square ( $\square$ ) mean is response to the unsupplemented diet (D1; not included in regression fit).

Lys is often considered first limiting in fish diets when substituting alternative proteins of plant origin, particularly corn products, for fishmeal and when the ideal pattern is based on either the whole body or muscle AA profile of that fish. In broilers fed corn-soybean diets, total sulfur amino acids (TSAA), Lys, and Thr are typically first, second, and third limiting (Kidd et al., 1997). However, in addition to soy and corn gluten, the fishmeal-free diet in our study included a substantial amount (13\%) of animal protein in the form of poultry by-product meal (PBM). PBM is recognized as a high quality protein for hybrid striped bass diets with a well characterized profile of amino acids and availability coefficients (Gaylord et al., 2004; Metts et al., 2011; Yu, 2008). Therefore, the inclusion of PBM in an otherwise plant-based formula significantly influenced the profile of the basal (D1) diet such that Lys was not first-limiting.

Instead, several results of the current study corroborate the prediction that Met was first-limiting. First, Lys retention was much lower in the unsupplemented basal diet than in the supplemented diets, whereas Met retention exhibited the opposite effect. Secondly, Lys retention decreased exponentially with increasing diet concentration, whereas, Met retention exhibited a very slow linear decline as dietary Lys increased five fold. If Lys were first limiting we would not expect Lys retention of a completely unsupplemented diet and putatively Lys deficient, to increase in the next diet of the series (D2) in which Lys level remained the same but Met and Thr were added, unless one of the two added amino acids were first limiting. Grisdale-Helland et al. (2011) observed that when all other amino acids were balanced in diets for Atlantic salmon in which Lys was first limiting, Lys retention was slightly higher, not lower, in the Lys deficient state and decreased in a slow linear fashion with increasing dietary Lys concentration. The fact that Met retention dropped from $68 \%$ in the unsupplemented diet (D1) to $37 \%$ in the supplemented basal diet (D2) in which only Met and Thr were added (no added Lys) also indicates that the target level of Met may have been supra-optimal. This result might ensue if the level of Met in the ideal protein overestimated the true requirement and/or the levels and/or availabilities of Met in the actual protein sources significantly differed from those in our current ingredient database. Boisen et al. (2000) point out that estimates of TSAA requirements depend in part on chemical analyses that are very susceptible to degradation during acid hydrolysis leading to an overestimate of the requirement. Also, fairly precise knowledge of amino acid availability in feedstuffs relative to their requirements is required for accurate supplementation of diets (Boisen et al., 2000). Hence, the constant refinement of our database (Barrows et al., 2011) of nutrient composition and availability coefficients over the long run should provide more accurate supplementation targets.

Grisdale-Helland et al. (2011) found that retentions of protein and the sum of the EAA followed quadratic functions with maxima at the optimum Lys level for their dietary formula. Although protein retention in our study did not show a clear maxima, the R95-R99 levels of Lys required to maximize total diet energy retention and protein accretion closely bracketed $(\approx 3-4 \mathrm{~g}$ Lys/100 g diet) the level of Lys suggested by HSB (3.5 g Lys/100 g diet) and trout muscle (3.9 g Lys/100 diet). Moreover, the level of Lys intake required to sustain maximal protein deposition in Atlantic salmon ( 0.12 to $0.16 \mathrm{~g}$ Lys/fish/d) was nearly identical to our results ( 0.10 to $0.16 \mathrm{~g}$ Lys/fish/d), even though we found a strong quadratic relationship with respect to Lys in the diet, whereas Espe et al. (2007) fit an exponential model to protein accretion in Atlantic salmon. It should be noted that there is no onus that a particular model and its estimated parameters have a direct underlying physical or biological significance (Ratkowski, 1990); nevertheless, the cubic model found parsimonious to most of the retention efficiencies reasonably tracts expected retention in the region of dietary Lys closely bracketing the optimum. In this scenario, one might expect retention efficiency to be slightly higher in the Lys deficient state, decline rapidly to a minima at a low intermediate but deficient dietary Lys, increase again to a maxima when the diet level is replete, then decline rapidly as Mercer et al. (1989) suggested when Lys concentration in the diet becomes inhibitory.

It is interesting that His response was both quadratic with respect to dietary Lys and that the R95 level of Lys required to maximize His retention $(3.1 \mathrm{~g} / 100 \mathrm{~g})$ was lower than that for Thr $(3.7 \mathrm{~g} / 100 \mathrm{~g})$. His was predicted to be fourth limiting in the basal formula at $33 \%$ lower concentration than the muscle level, whereas Thr was predicted to be third limiting at 38\% lower than the muscle (Table 2). The quadratic response and lower R95 requirement of His may be additional indicators of the sensitivity of the ideal protein method for predicting limiting amino acids in a particular formula given a reliable matrix of ingredient digestibility values. However, the R95 level of Lys required to maximize retentions of the branched chain amino acids Leu (not limiting) and Val (sixth limiting) were moderately higher than that of Thr (third limiting) and significantly higher than that of His (fourth limiting) and Arg (fifth limiting). Because Lys is not utilized for the synthesis of other nitrogen containing compounds, using Lys to set the ratio of other dietary EAA 
could have underestimated the metabolic demands of other essential AA relative to Lys (Boisen et al., 2000). Since its primary use will be for muscle, particularly muscle myosin (Berge et al., 1994), Lys might not be first limiting for metabolism and growth, whereas other EAA may be partitioned toward metabolic needs in ratios differing from those predicted by muscle profiles. Indeed, Twibell et al. (2003) applied this principle to optimize the performance of semipurified diets with respect to a fishmeal control for hybrid striped bass by supplementing Thr, Ile, and Trp at levels higher than those predicted by the whole body profile.

Because Lys was not first limiting and a suboptimal level of Met may have been targeted for formulation, additional shifts in the order of limitation and relative interactions among other EAA may have occurred given the mix of feedstuffs we included in the test diets. Interactions between branched chain amino acids (BCAA) and Lys are evident in the literature, for example, and Leu and Ile are particularly imbalanced in corn gluten (Mente et al., 2003), one of the three protein sources in our diets. Leu in particular interacts with Lys-Arg at the level of absorption (Berge et al., 1998; Mailliard et al., 1995) and is a key regulator of mRNA translation and proteolysis (Kimball and Jefferson, 2004). Hence, a dietary imbalance in BCAAs can result in poorer utilization of protein in plant products (Hughes, 1985 ) and poorer lean growth (Choo et al., 1991) that can be ameliorated with proper supplementation (Yamamoto et al., 2004). Interactions between Lys and Thr, are also known to have opposite effects on weight gain vs. lean muscle growth in poultry (Kidd et al., 1997), while maintenance requirements in relation to total requirements for Thr are also greater than that for Lys in swine (Moughan, 1995). Although there were significant differences in Arg retention efficiencies, as previously noted, we did not observe differences ( $p=$ $0.332 ; \mathrm{R}^{2}=0.043$; data not shown) in whole body Arg concentrations in hybrid striped bass in response to the Lys level of the diet. This is in spite of the fact that Lys:Arg tended to increase with increasing Lys in the diet such that the ratio in diets 8 and 9 were 2.41 and 2.65 , respectively, which are about 1.5 to 1.8 times larger than the same ratio in the median range diets (5-7). Nevertheless, competition between Lys and Arg at the level of transport across the brush-border membrane is also well documented (Berge et al., 1999; Vilella et al., 1990) and decreasing muscle Arg content in response to over supplementation of Lys has been attributed to this interaction in Atlantic salmon (Berge et al., 1998). Berge et al. (2002) later suggested that lysine may inhibit arginine availability in fish muscle tissue as well, based on utilization of $\mathrm{U}-\mathrm{C}^{14}$ arginine injected into the abdominal cavity. Conversely, Zhou et al. (2010) found increasing muscle Lys in response to increasing Arg in the diet of black sea bream. Therefore, our results indicate that additional research is needed to determine the optimum balance between all first four limiting amino acids in fishmeal-free diets for hybrid striped bass in order to maximize lean gain and minimize nitrogen loss.

Because graded Lys $\mathrm{HCl}$ was added to our diets at the expense of wheat starch, rather than balanced with dietary dispensable amino acids, protein to energy ratio varied slightly among the dose-response diets. There is some suggestion that the efficiency of utilization of first limiting EAA in fish may decrease with increasing dietary protein (Cowey and Cho, 1993). In the first case, it was important to employ commercial style diets in our feeding trial, which as matter of practice would not be balanced for nitrogen. Secondly, the variation in P:E (gross) was slight (about $20-23 \mathrm{~g} / \mathrm{MJ}$ ) among all test diets in our study, but relatively flat among most of the supplemented diets (D2 to D7). Finally, Lys retention efficiency in swine was not altered by dietary protein concentration (Langer and Fuller, 1996) nor Thr retention in Atlantic salmon fry (Abboudi et al., 2007). On the other hand, Encarnação et al. (2004) determined that changing the digestible energy content of trout diets altered Lys utilization but not requirement level. More likely, the form of protein provision, intact vs. peptide vs. free amino acid, has a more profound affect on utilization efficiency than the dietary protein level itself (Dabrowski et al., 2010; Yamamoto et al., 2005).

Because the dose-response diets included a high percentage of soybean meal (45\%), it was critical to discern if fish responses to different dietary Lys levels could be confounded with soy effects. Dietary inclusion of soy proteins has been associated with the development of enteritis and non-inflammatory pathologic changes in a number of different fish species including Atlantic salmon, rainbow trout, and common carp (Laporte and Trushenski, 2012; Urán et al., 2008a,b). Commonly, salmonids exhibit a heightened sensitivity to soy protein inclusion, inducing a variety of host responses ranging from morphological changes of the gut epithelium, marked inflammation, induction of cellular stress responses, and changes in bacterial microbiota (Bakke-McKellep et al., 2007; Urán et al., 2008b). Indeed, in Atlantic salmon, signs of enteritis were apparent by $7 \mathrm{~d}$ of continuous feeding with formulated diets containing 20\% soybean meal (Urán et al., 2008b). Alternatively, in hybrid striped bass, inclusion of high dietary levels of soybean meal, approximately $80 \%$ soybean meal for an 8 -week feeding regimen, failed to induce any major disruption of intestinal tissues (Laporte and Trushenski, 2012). Similarly, in the present study, a $45 \%$ level of soybean meal inclusion induced no apparent signs of enteritis. The precise mechanisms controlling the differential susceptibility of various food fish species to soybean meal remain elusive. However, enteritis development can be strongly influenced by differing commercial sources of soybean meal, and is exacerbated by increasing water temperatures (Urán et al., 2008b, 2009). In the context of intestinal pathology, the present findings confirm and extend those of previous reports demonstrating that hybrid striped bass may be less sensitive to soybean meal-induced enteritis than salmonids. Future studies should further investigate the apparent differences in sensitivities among taxa, as an improved understanding of the events controlling enteritis development will facilitate the development of improved feeds.

In conclusion, hybrid striped bass muscle appears to present a reasonable pattern of essential amino acid ratios and levels to target for optimizing commercial fishmeal-free diets for this taxon given our current database of ingredient profiles and availabilities. There is also evidence that the ideal protein method in this context is a sensitive indicator of order of limitation with some caveats that may be resolved with more careful analytical determination of TSAA levels and more accurate long-run averages of nutrient availabilities in our growing database. Finally, hybrid striped bass appear to be much less sensitive to soy derived antinutritional factors than other commercial aquaculture species.

\section{Acknowledgments}

We gratefully acknowledge the following individuals and companies for their material contributions to this research: Poultry products Chuck Malone, Tyson Foods, Inc.; Menhaden fish oil - Nancy Near, Omega Protein, Inc.; Menhaden fish meal, Select ${ }^{\mathrm{TM}}$ - Jim Stewart, Omega Protein, Inc.; Soybean meal - Archer Daniels Midland Co.; Wheat starch - Manildra Milling, Inc.; DL-Methionine, Lysine- $\mathrm{HCl}$, and Threonine - ADM Alliance Nutrition, Inc. We also thank USDA/ARS Technician Rebecca Jacobs for her substantial efforts in daily animal husbandry, sampling, and chemical analyses, as well as the following USDA/ARS personnel for their timely help during tissue sampling: Troy Bader, Matt Barnett, Bradley Farmer, Bobby Kelly, and Greg O'Neal. Finally, USDA/ ARS technician Jason Frost was instrumental in extruding the high quality test diets.

Mention of trade names or commercial products in this article is solely for the purpose of providing specific information and does not imply recommendation or endorsement by the U.S. Department of Agriculture. This study was funded by the USDA/ARS under project number 6225-31630-006-00D. USDA is an equal opportunity provider and employer. 


\section{References}

Abboudi, T., Ooghe, W., Larondelle, Y., Rollin, X., 2007. Determination of the threonine requirement for maintenance in Atlantic salmon (Salmo salar L.) fry with the diet dilution procedure. Aquaculture Nutrition 13, 281-290.

AOAC (Association of Official Analytical Chemists), 2005. AOAC Official Methods, 18th edition. Association of Official Analytical Chemists, Incorporated, Arlington, VA (364 pp.).

AOCS (American Oil Chemists Society), 2009. Official Methods and Recommended Practices of the American Oil Chemists Society, 6th edition. American Oil Chemists Society, Champaign, IL (200 pp.).

Bakke-McKellep, A.M., Penn, M.H., Salas, P.M., Refstie, S.S., Landsverk, T., Ringo, E., Krogdahl, A., 2007. Effects of dietary soyabean meal, inulin and oxytetracycline on intestinal microbiota and epithelial cell stress, apoptosis and proliferation in the teleost Atlantic salmon (Salmo salar L.). British Journal of Nutrition 97, 699-713.

Barrows, F.T. Gaylord, T.G., Sealey, W. Rawles, S.D., 2011. Database of nutrient digestibility's of traditional and novel feed ingredients for trout and hybrid striped bass. http://www.ars.usda.gov/Main/docs.htm?docid=219052011 (Last accessed on $10 / 15 / 12$ )

Berge, G.E., Lied, E., Espe, M., 1994. Absorption and incorporation of dietary free and protein bound $\left(\mathrm{U}^{14} \mathrm{C}\right)$-lysine in Atlantic cod (Gadus morhua). Comparative Biochemistry and Physiology 109A, 681-688.

Berge, G.E., Sveier, H., Lied, E., 1998. Nutrition of Atlantic salmon (Salmo salar): the requirement and metabolic effect of lysine. Comparative Biochemistry and Physiology $120 \mathrm{~A}, 477-485$.

Berge, G.E., Bakke-McKellep, A.M., Lied, E., 1999. 'In vitro' uptake and interaction between arginine and lysine in the intestine of Atlantic salmon (Salmo Salar). Aquaculture 179, 181-193.

Berge, G.E., Sveier, H., Lied, E., 2002. Effects of feeding Atlantic salmon (Salmo salar L.) imbalanced levels of lysine and arginine. Aquaculture Nutrition 8, 239-248.

Boisen, S., Hvelplund, T., Weisber, M.R., 2000. Ideal amino acid profiles as a basis for feed protein evaluation. Livestock Production Science 64, 239-251.

Brown, P.B., 1995. Using whole-body amino acid patterns and quantitative requirements to rapidly develop diets for new species such as striped bass (Morone saxatilis). Journal of Applied Ichthyology 11, 342-346.

Choo, P.S., Smith, T.K., Cho, C.Y., Ferguson, H.W., 1991. Dietary excesses of leucine influence growth and body composition of rainbow trout. Journal of Nutrition 121, 1932-1939.

Cowey, C.B., Cho, C.Y., 1993. Nutritional requirements of fish. Proceedings of the Nutrition Society $52,417-426$

Dabrowski, K., Zhang, Y., Kwasek, K., Hliwa, P., Ostaszewska, T., 2010. Effects of protein-, peptide- and free amino acid-based diets in fish nutrition. Aquaculture Research 41, 668-683.

Encarnação, P., de Lange, C., Rodehutscord, M., Hoehler, D., Bureau, W., Bureau, D.P., 2004. Diet digestible energy content affects lysine utilization, but not dietary lysine requirements of rainbow trout (Oncorhynchus mykiss) for maximum growth. Aquaculture 235, 569-586.

Espe, M., Lemme, A., Petri, A., El-Mowafi, A., 2007. Assessment of lysine requirement for maximal protein accretion in Atlantic salmon using plant protein diets. Aquaculture 263, 163-178.

Espe, M., Hevrøy, E.M., Liaset, B., Lemme, A., El-Mowafi, A., 2008. Methionine intake affect hepatic sulphur metabolism in Alt salmon, Salmo Salar. Aquaculture 274, 132-141.

Fuller, M.F., Livingstone, R.M., Bard, B.A., Atkinson, T., 1979. The optimal amino acid supplementation of barley for the growing pig. 1. Response of nitrogen metabolism to progressive supplementation. British Journal of Nutrition 41, 321-331.

Fuller, M.F., McWilliam, R., Wang, T.C., Giles, L.R., 1989. The optimum amino acid amino for growing pig. 2. Requirement for maintenance and for tissue protection accretion. British Journal of Nutrition 62, 255-261.

Gaylord, T.G., Barrows, F.T., 2009. Multiple amino supplementations to reduce dietary protein in plant-based rainbow trout, Oncorhynchus mykiss, feeds. Aquaculture 287, 180-194.

Gaylord, T.G., Rawles, S.D., 2005. The modification off poultry by-product meal for use in hybrid striped bass Morone chrysops x M. saxatilis diets. Journal of the World Aquaculture Society 36, 365-376.

Gaylord, T.G., Rawles, S.D., Gatlin III, D.M., 2004. Amino acid availability from animal, blended, and plant feedstuffs for hybrid striped bass (Morone chrysops $\times$ M. saxatilis). Aquaculture Nutrition 10, 345-352.

Griffin, M.E., Brown, P.B., Grant, A.L., 1992. The dietary lysine requirement of juvenile hybrid striped bass. Journal of Nutrition 122, 1332-1337.

Griffin, M.E., White, M.R., Brown, P.B., 1994. Total sulfur amino acid requirement and cysteine replacement value for juvenile hybrid striped bass Morone saxatilis $\times$ M. chrysops. Comparative Biochemistry and Physiology 108A, 423-429.

Grisdale-Helland, B., Gatlin III, D.M., Corrent, E., Helland, S.J., 2011. The minimum dietary lysine requirement, maintenance requirement and efficiency of lysine utilization for growth of Atlantic salmon smolts. Aquaculture Research 42, 1509-1529.

Henderson, J.W., Ricker, R.D., Bidlingmeyer, B.A., Woodward, C., 2006. Rapid, accurate sensitive, and reproducible HPLC analysis of amino acids. Application Note No. 5980-1193EN.Agilent Technologies, Wilmington, DE (http://www.chem.agilent. com/Library/applications/AAA\%20technote.pdf last accessed October 15, 2012).

Hickling, E., Guenter, W., Jackson, M.E., 1990. The effects of dietary methionine and lysine on broiler chicken performance and breast meat yield. Canadian Journal of Animal Science 70, 673-678.

Hughes, S.G., 1985. Evaluation of glutamic acid and glycine as sources of non-essential amino acids for lake trout (Salvelinus namaycush) and rainbow trout (Salmo gairdneri). Comparative Biochemistry and Physiology 81, 671-699.

Keembiyehetty, C.N., Gatlin III, D.B., 1992. Dietary lysine requirement of juvenile hybrid striped bass. Aquaculture 104, 271-277.
Keembiyehetty, C.N., Gatlin III, D.B., 1993. Total sulfur amino acid requirement of juvenile hybrid striped bass, Morone chrysops M. saxatilis. Aquaculture 110, 331-339.

Keembiyehetty, C.N., Gatlin III, D.B., 1997. Dietary threonine requirement of juvenile hybrid striped bass (Morone chrysops $\times$ M. saxatilis). Aquaculture Nutrition 3, 217-221.

Kidd, M.T., Kerr, B.J., Anthony, N.B., 1997. Dietary interactions between lysine and threonine in broilers. Poultry Science 76, 608-614.

Kimball, S.R., Jefferson, L.S., 2004. Regulation of global and specific mRNA translation by oral administration of branched chain amino acids. Biochemical and Biophysical Research Communications 313, 423-427.

Kvalseth, T.O., 1985. Cautionary note about $\mathrm{R}^{2}$. The American Statistician 39, 279-285.

Langer, S., Fuller, M.F., 1996. The effects of excessive amounts of protein on lysine utilization in growing pigs. British Journal of Nutrition 76, 743-754.

LaPorte, J., Trushenski, J., 2012. Production performance, stress tolerance and intestinal integrity of sunshine bass fed increasing levels of soybean meal. Journal of Animal Physiology and Animal Nutrition 96, 513-526.

Mailliard, M.E., Stevens, B.R., Mann, G.E., 1995. Amino acid transport by small intestinal hepatic and pancreatic epithelia. Gastroenterology 108, 888-910.

Mente, E., Deguara, S., Santos, M.B., Houlihan, D., 2003. White muscle free amino acid concentrations following feeding a maize gluten dietary protein in Atlantic salmon (Salmo salar L.). Aquaculture 225, 133-147.

Mercer, L.P., May, H.E., Dodds, S.J., 1989. The determination of nutritional requirements in rats: mathematical modeling of sigmoidal, inhibited nutrient-response curves. Journal of Nutrition 119, 1465-1471.

Metts, L.S., Rawles, S.D., Brady, Y.J., Thompson, K.R., Gannam, A.L., Twibell, R.G. Webster, C.D., 2011. Amino acid availability from selected animal- and plantderived feedstuffs for market-size sunshine bass (Morone chrysops $\times$ Morone saxatilis). Aquaculture Nutrition 17, e123-e131.

Moran Jr., E.T., Bilgili, S.F., 1990. Processing losses, carcass quality and meat yield of broiler chickens receiving diets marginally deficient to adequate in lysine prior to marketing. Poultry Science 69, 702-710.

Moughan, P.J., 1995. Modelling protein metabolism in the pig - critical evaluation of a simple reference model. In: Moughan, P.J., Verstegen, M.W.A., Visser-Reyneveld, M.I. (Eds.), Modelling Growth in the Pig. EAAP Publ. No. 78. Wageningen Press, The Netherlands, pp. 103-112.

NRC (National Research Council NRC), 2011. Nutrient Requirements of Fish and Shrimp. The National Academies Press, Washington, D.C.(376 pp.).

Rathore, R.M., Liaset, B., Hevrøy, E.M., El-Mowafi, A., Espe, M., 2010. Lysine limitation alters the storage pattern of protein, lipid and glycogen in on-growing Atlantic salmon. Aquaculture Research 41, e751-e759.

Ratkowski, D.A., 1990. Handbook of Nonlinear Regression Models. Marcel Dekker, Inc. New York, NY (241 pp.).

Rawles, S.D., Gaylord, T.G., McEntire, M.E., Freeman, D.W., 2009. Evaluation of poultry by-product meal in commercial diets for hybrid striped bass, Morone chrysops 우 $\times$ Morone saxatilis ${ }^{7}$, in pond production. Journal of the World Aquaculture Society 40, 141-156.

Rawles, S.D., Thompson, K.R., Brady, Y.J., Metts, L.S., Aksoy, M.Y., Gannam, A.L., Twibell, R.G., Ostrand, S., Webster, C.D., 2011. Effects of replacing fishmeal with PBM \& SBM and reduced protein on hybrid striped bass performance and immune response in ponds. Aquaculture Nutrition 17, e708-e721.

Rawles, S.D., Green, B.W., Gaylord, T.G., Barrows, F.T., McEntire, M.E., Freeman, D.W., 2012. Response of sunshine bass (Morone chrysops $\times$ M. saxatilis) to digestible protein/dietary lipid density and ration size at summer culture temperatures in the Southern United States. Aquaculture 356-357, 80-90.

Rayner, C.J., 1985. Protein hydrolysis of animal feeds for amino acid content. Journal of Agricultural and Food Chemistry 33, 722-725.

Rodehutscord, M. Pack, M., 1999. Estimates of essential amino acid requirements from dose-response studies with rainbow trout and broiler chicken: effect of mathematical model. Archives of Animal Nutrition 53, 223-244.

Small, B.C., Soares Jr., J.H., 1998. Estimating the quantitative essential amino acid requirements of striped bass Morone saxatilis, using fillet A/E ratio. Aquaculture Nutrition 4, 225-232.

Stevens, A., Wilson, I., 1996. The haematoxylins and eosin. In: Bancroft, J.D., Stevens, A (Eds.), Theory and Practice of Histological Techniques. Churchill Living, New York, NY, pp. 99-112.

Twibell, R.G., Griffin, M.E., Martin, B., Price, J., Brown, P.B., 2003. Predicting dietary amino acid requirements for hybrid striped bass. Aquaculture Nutrition 9, 373-381.

Urán, P.A., Gonçalves, A.A., Taverne-Thiele, J.J., Schrama, J.W., Verreth, J.A., Rombout, J.H., 2008a. Soybean meal induces intestinal inflammation in common carp (Cyprinus carpio L.). Fish \& Shellfish Immunology 25, 751-760.

Urán, P.A., Schrama, J.W., Rombout, J.H.W.M., Obach, A., Jensen, L., Koppe, W., Verreth, J.A.J., 2008b. Soybean meal-induced enteritis in Atlantic salmon (Salmo salar L.) at different temperatures. Aquaculture Nutrition 14, 324-330.

Urán, P., Schrama, J.W., Jaafari, S., Baardsen, G., Rombout, J.H.W.M., Koppe, W. Verreth, J.A.J., 2009. Variation in commercial sources of soybean meal influences the severity of enteritis in Atlantic salmon (Salmo salar L.). Aquaculture Nutrition $15,492-499$.

Vilella, S., Ahearn, G.A., Cassano, G., Maffia, M., Storelli, C. 1990. Lysine transport by brush-border membrane vesicles of eel intestine: interaction with neutral amino acids. American Journal of Physiology - Regulatory, Integrative and Comparative Physiology 259, R1181-R1188.

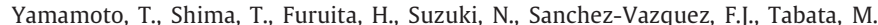
2001. Self-selection and feed consumption of diets with a complete amino acid composition and a composition deficient in either methionine or lysine by rainbow trout Oncorhynchus mykiss (Walbaum). Aquaculture Research 32 (Suppl. 1), 83-91. 
Yamamoto, T., Shima, T., Furuita, H., 2004. Antagonistic effects of branched-chain amino acids induced by excess protein-bound leucine in diets for rainbow trout (Oncorhynchus mykiss). Aquaculture 232, 539-550.

Yamamoto, T., Sugita, T., Furuita, H., 2005. Essential amino acid supplementation to fish meal-based diets with low protein to energy ratios improves protein utilization in juvenile rainbow trout Oncorhynchus mykiss. Aquaculture 246, 379-391.
Yu, Y., 2008. Replacement of fish meal with poultry by-product meal and hydrolyzed feather meal in feeds for finfish. In: Lim, C.E., Webster, C.D., Lee, C.S. (Eds.), Alternative Protein Sources in Aquaculture Diets. Haworth Press, New York, NY, pp. 51-93.

Zhou, F., Xiong, W., Xiao, J.-X., Shao, Q.-J., Bergo, O.N., Hua, Y., Chai, X., 2010. Optimum arginine requirement of juvenile black sea bream, Sparus macrocephalus. Aquaculture Research 41, e418-e430. 